\title{
Cerkiew prawosławna w II Rzeczypospolitej
}

\author{
Antoni Mironowicz \\ Wydział Historii i Socjologii, Uniwersytet w Białymstoku \\ Białystok, Polska \\ amir@uwb.edu.pl
}

A. Mironowicz, The Orthodox Church, 2nd Polish Republic, Elpis, 20 2018: 85-109.

\begin{abstract}
In 1918 the independent republic of Poland was proclaimed. In 1920-1921, after the Polish-Soviet war, the Polish border was moved $200 \mathrm{~km}$ east of the Curzon line, which is more or less the Soviet-polish border of 1945. During the 2nd Polish Republic the Orthodox Church was not supported by an ascendancy of the authority yet, but was identified with the Russian invader's religion. The Polish authorities treated Orthodoxy not as the religion of their people, but as the faith of the former occupant. The transfer of Orthodox Church property was part of the government's policy of building a revived Polish state and its national unity on the basis of Roman Catholicism. This policy meant decreasing the number of Orthodox parishes and monasteries, the confiscation of church property by the state or its transfer to the Roman Catholic Church, closing Orthodox churches, and converting the faithful to Roman Catholicism.

Throughout the mid-war period (1938-1939) the Orthodox Church had no regulated legal status. It was only after the transfer of Orthodox churches and estates by the state and the Roman Catholic Church that president Ignacy Mościcki signed a decree of 18 November 1938 On the attitude towards the Autocephalous Orthodox Church. On the basis of that decree the position of the highest authority governing the matters of the Autocephalous Orthodox Church was given to the General Council (Sobor) which consisted of bishops and representatives of the clergy and faithful. The executive body of the Church was a synod consisting of the metropolitan, the army bishop and two diocese bishops.

The 1938 decree was the first document in the history of the Orthodox Church in the Second Polish Republic, which settled the relations between the Polish state and the Orthodox Church. It removed the state temporariness criticised by the clergy and faithful. On the basis of this decree the Orthodox Church was greatly subjected to the state and its policy. Within three weeks of issuing the decree, on 10 December 1938, a governmental decree was issued containing "The Internal Statute of the Polish Autocephalous Orthodox Church". It settled in detail the competence of the Orthodox metropolitan, the General Council, the Bishops' Council and the Bishops' Synod.
\end{abstract}

Streszczenie: Po odrodzeniu się państwa polskiego, w okresie II Rzeczypospolitej prawosławie nie było już wspierane autorytetem władzy, ale było utożsamiane z wyznaniem zaborcy. Przemiany społeczno-ustrojowe w Rosji Radzieckiej osłabiły pozycję patriarchatu moskiewskiego, który nadał Kościołowi prawosławnemu w Polsce autonomię, a kierownictwo nad nim powierzył lokalnemu soborowi biskupów z egzarchą o uprawnieniach metropolity. W latach 1918-1939 Kościół prawosławny w granicach Rzeczypospolitej liczył ponad 4 miliony wiernych i był podzielony na siedem diecezji. Władze polskie z jednej strony dążyły do ustanowienia niezależnej od Moskwy struktury cerkiewnej, z drugiej zaś ograniczały liczbę parafii prawosławnych i jego rolę w społeczeństwie.

Odpowiedź na pytanie o pozytywne i negatywne fakty w dziejach prawosławia na terenie II Rzeczypospolitej wymaga całościowego spojrzenia na politykę państwa wobec Cerkwi w latach 1918-1939. Do pozytywnych procesów należy zaliczyć unormowanie się stanu prawnego Kościoła prawosławnego w państwie polskim. Co prawda ostateczne uregulowanie stanu prawnego na mocy Przepisów Tymczasowych z 1922 roku i dekretu Prezydenta RP z 1938 roku nie zadawalały ani władze państwowe ani cerkiewne to było ważnym etapem na drodze budowania osobowości prawnej Cerkwi. Dekret stwierdził autokefaliczność Kościoła prawosławnego w Polsce oraz prawo swobodnego rządzenia się w granicach ustawodawstwa państwowego. Głową Kościoła, jego naczelnym zarządcą i przedstawicielem był metropolita, który był jednocześnie arcybiskupem diecezji warszawskiej i archimandrytą Ławry Poczajowskiej. Organem najwyższym Kościoła, regulującym sprawy Polskiego Autokefalicznego Kościoła Prawosławnego, był Sobór Generalny składający się z biskupów oraz przedstawicieli duchowieństwa i świeckich. Sobór Generalny mógł zmienić ustrój Kościoła z dominującego w latach 1918-1938 ustroju synodalno-konsystorskiego, w którym naczelną władzę posiadał Synod biskupów na ustrój soborowy, oparty na zasadach wybieralności episkopatu i dziekanów z czynnym głosem przedstawicieli wiernych. Organem wykonawczym Soboru Biskupów był Synod składający się z metropolity, który był jego przewodniczącym, biskupa wojskowego i 2 biskupów diecezjalnych.xxx

Keywords: The Orthodox Church, 2nd Polish Republic

Słowa kluczowe: Cerkiew prawosławna, II Rzeczpospolita

Rzeczpospolita Polska przez cały okres międzywojenny była państwem wielonarodowościowym i wielowyznaniowym. Strukturę narodowościową i wyznaniową społeczeństwa II Rzeczypospolitej możemy scharakteryzować na podstawie spisów ludności z 1921 i 1931 r. Oba spisy były obarczone licznymi błędami formalnymi i merytorycznymi. Spis ludności z 1921 r. nie obejmował terytorium całego państwa polskiego i został dokonany w okresie znacznych przemieszczeń ludnościowych. W tym czasie prowadzona była repatriacja ludności, która w 1915 r. opuściła swoje miejsca zamieszkania. Tereny byłego zaboru pruskiego opuszczali Niemcy i część ludności żydowskiej. W okresie od 31 listopada 1921 r. do 31 grudnia 1922 r. do Polski przybyło 489,2 tys. repatriantów, którzy nie zostali ujęci w danych spisowych. Wiele zastrzeżeń budził sposób przeprowadzenia spisu, bez jasnych kryteriów określają- 
cych wyznanie i narodowość ludności'. Mając powyższe kwestie na uwadze wyniki pierwszego powszechnego spisu ludności II Rzeczypospolitej w części dotyczącej mniejszości narodowych można traktować jako szacunkowe. Pomimo tych mankamentów spis z $1921 \mathrm{r}$. jest podstawą do określenia przybliżonej liczby wiernych poszczególnych Kościołów i związków wyznaniowych. Według danych spisowych $63,8 \%$ społeczeństwa było wyznania rzymskokatolickiego, $11,2 \%$ greckokatolickiego, 10,5\% prawosławnego, $3,7 \%$ ewangelickiego, $10,5 \%$ mojżeszowego, a $0,3 \%$ innych związków religijnych. Najwięcej wyznawców prawosławia zamieszkiwało województwo poleskie $-79,2 \%$, wołyńskie $-74,2 \%$, nowogródzkie $-51,1 \%$, białostockie - 15,1\% i w okręgu wileńskim - 26,9\%. W pozostałych województwach procentowy współczynnik ludności wyznania prawosławnego nie przekraczał $1 \%{ }^{2}$.

Spis ludności z 1931 r. odbywał się po zakończeniu migracji ludności, ale sposób jego przeprowadzenia budził wiele wątpliwości co do ostatecznych wyników. Na jego podstawie szacuje się, że państwo polskie było zamieszkałe przez 20,6 mln wyznawców Kościoła rzymskokatolickiego (64,8\%), 3,8 mln Kościoła prawosławnego (11,8\%), 3,3 mln Kościoła greckokatolickiego (10,4\%), 3,1 mln wyznania mojżeszowego (9,8\%), 875 tys. Kościoła ewangelickiego (2,6\%) i 197 tys. innych związków religijnych (0,6\%). Ludność prawosławna zamieszkiwała głównie w województwie poleskim - 77,4\% ogółu mieszkańców województwa, wołyńskim - 69,8\%, nowogródzkim $51,3 \%$, wileńskim $-25,4 \%$, białostockim $-18,5 \%$, lubelskim $-8,5 \% \mathrm{~W}$ każdym z pozostałych województw ludność prawosławna stanowiła poniżej 1\% mieszkańców³. Z powyższej statystyki wynika, że przynajmniej w trzech

R. Buławski, Projekt drugiego spisu powszechnego na tle doświadczeń spisu z 1921 r., „Kwartalnik Statystyczny”, 1930, z. 1; J. Tomaszewski, Ojczyzna nie tylko Polaków. Mniejszości narodowe w Polsce w latach 1918-1939, Warszawa 1985; M. Siemakowicz, Spisy ludności a zagadnienia narodowościowe z uwzględnieniem spraw szkolnictwa dla mniejszości białoruskiej w II Rzeczypospolitej, „Białoruskie Zeszyty Historyczne", 1998, nr 10, s. 85.

2 Historia Polski w liczbach. Ludność i terytorium (GUS), Warszawa 1993, s. 158. Nieco inne dane na podstawie tego samego spisu ludności podaje Kazimierz Urban. Według tego badacza wyznawcy Kościoła rzymskokatolickiego stanowili 62,5\% ogółu ludności kraju, Kościoła greckokatolickiego 11,8\%, Kościoła prawosławnego 11\%, Kościoła ewangelickiego $3,7 \%$, wyznania mojżeszowego $10,8 \%$ i innych $0,2 \%$. Por.: K. Urban, Prawosławni w strukturze wyznaniowej Polski, [w:] Kościót prawosławny w Polsce. Dawniej i dziś, pod red. L. Adamczuka i A. Mironowicza, Warszawa 1993, s. 35; G. J. Pelica, Kościót prawosławny w województwie lubelskim (1918-1939), Lublin 2007, s. 34-35.

3 Historia Polski w liczbach., s. 161-164; M. Papierzyńska-Turek, Organizacja Kościoła Prawosławnego w latach 1918-1939, [w:] Kościót Prawostawny w Polsce dawniej i dziś, s. 59. Więcej na temat liczebności poszczególnych grup narodowościowych por.: J. Żarnowski, Społeczeństwo II Rzeczypospolitej 1918-1939, Warszawa 1973, s. 372-401; W. Mędrzecki, Liczebność i rozmieszczenie grup narodowościowych w II Rzeczypospolitej w świetle wyników II spisu powszechnego (1931), „Dzieje Najnowsze” 1983, nr 1/2, s. 231-252; W. Roszkowski, Historia Polski 1914-1998, Warszawa 1999, s. 32. Inne dane o procentowej licznie ludności prawosławnej w wymienionych województwach podaje S. Kiryłowicz, Niektóre problemy prawosławia na tle polityki wyznaniowej państwa w okresie międzywojennym, „Posłannictwo”, nr 3-4 (1979), s. 89; G. J. Pelica, Kościót prawosławny w województwie lubelskim (19181939), s. 38-39. województwach wyznawcy Kościoła prawosławnego stanowili większość mieszkańców. Ludność prawosławna pochodziła przeważnie ze środowisk mniejszości narodowych. Wyznawcami prawosławia było 1,5 mln Ukraińców, 900 tys. Białorusinów, 700 tys. tzw. „tutejszych”, 600 tys. Polaków oraz 125 tys. Rosjan ${ }^{4}$. Prawosławni w województwie nowogródzkim, poleskim, wileńskim i białostockim byli przeważnie narodowości białoruskiej, a na terenie województw wołyńskiego i lubelskiego narodowości ukraińskiej. Zdecydowana większość ludności prawosławnej mieszkało na wsi. Na ogólna liczbę 3762500 wiernych Kościoła prawosławnego ludność wiejska stanowiła 3571600 osób, a jedynie 190800 wyznawców zamieszkiwało w miastach ${ }^{5}$.

\section{Sytuacja prawno-organizacyjna}

Kościół prawosławny w II Rzeczypospolitej znalazł się w grupie wyznań mniejszościowych i stracił swoje dotychczasowe uprzywilejowane miejsce. Władze Rzeczypospolitej traktowały prawosławie jako relikt zaborcy i z niechęcią odnosiły się do jego wyznawców. Administracja państwowa i Kościół rzymskokatolicki rozpoczęły akcję rewindykacji świątyń i monasterów należących do Kościoła prawosławnego. Akcję tę można było łatwo przeprowadzić, albowiem w Cerkwi panował chaos organizacyjny. Duchowni prawosławni, którzy znajdowali się na terenie państwa polskiego, nadal stanowili integralną część Rosyjskiego Kościoła Prawosławnego. Priorytetową sprawą dla władz polskich było wyrwanie Kościoła prawosławnego na ziemiach polskich spod jurysdykcji moskiewskiej i uzyskanie dla niego autokefalii. W opinii władz takie działania wymagała polska racja stanu' ${ }^{6}$ Realizacja tej polityki była utrudniona z uwagi na ekspansję duchowieństwa katolickiego i jego odwetowe tendencje w stosunku do duchowieństwa prawosławnego. Dążenie kleru łacińskiego do zwiększenia materialnego stanu posiadania nie zawsze korelowało z interesami państwa ${ }^{7}$. Z kolei Rosyjski Kościół Prawosławny nie chciał utracić tak znaczącej części swojego stanu posiadania i zmierzał do utrzymania jedności prowincji cerkiewnej, pomimo zmian granic państwowych i sytuacji politycznej.

W latach 1917-1918 r. w Moskwie obradował Sobór Rosyjskiego Kościoła Prawosławnego, który przywrócił

\footnotetext{
K. Krasowski, Zwiazki wyznaniowe w II Rzeczypospolitej. Studium historyczno-prawne, Warszawa - Poznań 1988, s. 106.

5 „Wiadomości Metropolii Prawosławnej w Polsce”, nr 3 (11), 1939, s. 7.

6 A. Friszke, Kościoly wschodnie w Drugiej Rzeczpospolitej, „Więż” 1988, nr 7/8, s. 84. O polityce władz państwowych wobec wyznawców prawosławia, por:: A. Mironowicz, The Orthodox Church in Poland in the Twentieth Century, [in:] The Orthodox Church in Eastern Europe in Twentieth Century, ed. Christine Chaillot, Oxford - Bern 2011, s. 247267; tenże, L'Église orthodoxe en Pologne au XX siècle, [in:] L'Église orthodoxe en Europe orientale au XX siècle, sous la direction de Christine Chaillot, Paris 2009, s. 229-248.
}

K. Srokowski, Sprawa narodowościowa na kresach wschodnich, Kraków 1924, s. 42 
patriarchat i stworzył ustrój soborowy ${ }^{8}$. Podczas obrad tego soboru biskup wileński Tichon 13 sierpnia $1917 \mathrm{r}$. został wybrany na metropolitę moskiewskiego, a 21 listopada 1917 r. na patriarchę. Ważne decyzje zapadły również odnośnie diecezji warszawskiej. Sobór opracował zasady funkcjonowania diecezji warszawskiej i na jej ordynariusza wyznaczył arcybiskupa twerskiego Serafina (Cziczagowa). Postanowienia soboru władyka warszawski przekazał posłowi polskiemu w Moskwie Aleksandrowi Lednickiemu9. Rząd polski odrzucił kandydaturę arcybiskupa Serafina motywując tym, że władyka twerski nie posiadał obywatelstwa polskiego, a w obradach soboru nie uczestniczył przedstawiciel władz polskich ${ }^{10}$.

$\mathrm{Na}$ soborze moskiewskim zapadły również ważne postanowienia odnośnie innych diecezji. Patriarcha Tichon w 1918 r. polecił biskupowi krzemienieckiemu Dionizemu najpierw zarządzać diecezją chełmską, a następnie stworzyć nową diecezję poleską, składającą się z części eparchii mohylewskiej, mińskiej i grodzieńskiej ${ }^{11}$. Zwierzchnik Rosyjskiego Kościoła Prawosławnego wyznaczył swego wikarego biskupa Eleuteriusza (Bogojawleńskiego) na ordynariusza diecezji litewsko-wileńskiej, który już od $1915 \mathrm{r}$. zastępował abp. Tichona w kierowaniu diecezją. Władyka Eleuteriusz przybył do Wilna w końcu 1918 r. Patriarcha polecił również powrócić do swej diecezji biskupowi białostockiemu Włodzimierzowi (Wiaczesławowi Tichonickiemu), który przybył do Grodna 1 września 1918 r. ${ }^{12}$

Rząd polski, w myśl swojej polityki wyznaniowej, od razu stanął na stanowisku dostosowania terytorialnej organizacji cerkiewnej do granic państwowych. Na terenie ziem, które znalazły się w granicach państwa polskiego, formalnie funkcjonowało sześć diecezji prawosławnych (warszawska, chełmska, litewsko-wileńska, grodzieńska, wołyńska i poleska). Administrowanie dwoma istniejącymi pod zaborem rosyjskim diecezjami - warszawską i chełmską - powierzono władyce Włodzimierzowi, albowiem wyznaczony na władyctwo warszawskie arcybiskup Serafin i zarządzający przed 1918 r. eparchią chełmską biskup Eulogiusz nie mogli objąć wymienionych katedr. Biskup białostocki administrował diecezją grodzieńską. W tym samym czasie władyka krzemieniecki Dionizy kontynuował prace organizacyjne nad utworzeniem diece-

\footnotetext{
J. S. Langrod, O autokefalii prawosławnej w Polsce, Warszawa 1931, s. 49.

9 K. Krasowski, Zwiazki wyznaniowe..., s. 115.

10 Tamże, s. 16. Arcybiskup Serafin był nominalnym biskupem diecezji warszawskiej aż do 1922 r. Do czasu przeniesienia na drugą katedrę tytułowano go arcybiskupem warszawskim i przywiślańskim: Алексий (Громадский) архиепископ, К истории Православной Церкви в Польше за десятилетие пребывания во главе её Блаженнейшего Митрополита Дионисия (1923-1933), Варшава 1937, с. 14; tenże, О каноничности «Положения о внутреннем устройстве Православной Церкви в Польше», Варшава 1927.

11 А. Свитич, Православная Церковь в Польше и ее автокефалия, Буэнос-Айрес, 1959, с. 93; (Wydanie drugie w pracy: Православная Церковь на Украине и в Польше в ХХ столетии: 1917-1950 г2., Москва 1997, с. 93; A. Mironowicz, Kościót prawosławny w Polsce, Białystok 2016, s. 515.

12 Митрополит Владимир, святитель и молитвенник (18731959), Париж 1965, с. 30; В. И. Косик, Владимир „Православная энциклопедия", т. VIII, Москва 2004, с. 665-667.
}

zji poleskiej. Jako biskup krzemieniecki władyka Dionizy uczestniczył we Wszechukraińskim Soborze Cerkiewnym i brał udział w przygotowaniu projektu powołania Ukraińskiej Autokefalicznej Cerkwi Prawosławnej. Po zajęciu Kijowa przez bolszewików biskup Dionizy w końcu stycznia 1919 r. powrócił do Krzemieńca. Pomimo działań wojennych i choroby władyka krzemieniecki odbudował struktury parafialne w diecezji i od kwietnia 1920 r. sprawował nadzór nad życiem religijnym w eparchii wołyńskiej. Dopiero w sierpniu 1920 r. biskup Dionizy oficjalnie rozpoczął zarządzanie biskupstwem wołyńskim. Biskupstwo litewsko-wileńskie, kierowane przez biskupa Eleuteriusza, do 1922 r. pozostawało poza granicami kraju ${ }^{13}$.

Normalizacja spraw kanonicznych Kościoła prawosławnego w II Rzeczypospolitej wymagała uregulowania jego statusu prawnego. Proces kształtowania się stosunków państwo - Kościół prawosławny trwał niezmiernie długo i był bardzo skomplikowany. Nowe uwarunkowania polityczne wymagały zupełnie odmiennego podejścia do spraw Kościoła prawosławnego, albowiem na wcielonych do państwa ziemiach wciąż obowiązywało ustawodawstwo wyznaniowe państw zaborczych ${ }^{14}$. Traktat wersalski z 28 czerwca 1919 r. narzucał zobowiązania wobec mniejszości narodowych i wyznaniowych, które władze Rzeczypospolitej musiały zaakceptować. Rząd polski zobowiązał się do zapewnienia wszystkim mieszkańcom kraju, bez różnicy religii, narodowości i języka, ochrony swobodnego wykonywania praktyk religijnych, równości praw cywilnych itd. Sejm ratyfikował traktat wersalski w 1920 r. ${ }^{15}$ Zobowiązania rządu polskiego znalazły odzwierciedlenie w konstytucji z 17 marca 1921 r., która dała podstawy nowemu porządkowi prawnemu oraz nakreśliła w zarysie założenia polityki wyznaniowej. Założenia te zostały umieszczone w rozdziale piątym konstytucji: „Powszechne prawa i obowiązki obywatelskie"16. Artykuły 113-116 konstytucji poświęcone zostały związkom wyznaniowym. Artykuł 113 stwierdzał, że każdy związek wyznaniowy prawnie uznany przez państwo ma prawo urządzać nabożeństwa, posiadać samorząd do prowadzenia swych spraw wewnętrznych oraz posiadać osobowość prawną. Artykuł 114 zrównał w prawach wszystkie związki wyznaniowe, ale Kościołowi rzymskokatolickiemu przyznawał naczelne

\footnotetext{
13 A. Mironowicz, Kościół prawosławny na ziemiach polskich $w$ XIX $i$ XX wieku, Białystok 2005, s. 84-85; tenże, Kościót prawosławny w Polsce, s. 516.

14 M. Papierzyńska-Turek, Między tradycja, a rzeczywistością. Państwo wobec prawosławia 1918-1939, Warszawa 1989, s. 133, 134.

15 S. Żeleźniakowicz, Z historii Polskiego Kościoła Prawosławnego w okresie międzywojennym (1919-1939), „Wiadomości Polskiego Autokefalicznego Kościoła Prawosławnego” (dalej: „WPAKP”), 1981, nr 4, s. 43-44; Por.: Dz. U. nr 110/1920, poz. 728.

16 M. T. Staszewski, Wolność sumienia w II Rzeczypospolitej (Szkic zagadnienia), „Posłannictwo” 1986, nr 3/4 s. 117. Por.: H. Świątkowski, Wyznania religijne $w$ Polsce, ze szczególnym uwzględnieniem ich stanu prawnego, cz. I, Wyznania i zwiazki religijne, Warszawa 1937; J. Sawicki, Studia nad położeniem prawnym mniejszości religijnych $w$ państwie polskim, Warszawa 1937; M. T. Staszewski, Wolność sumienia przed trybunatem II Rzeczypospolitej, Warszawa 1970; H. Chałupczak, Status prawny i formy integracji mniejszości narodowej w Europie międzywojennej, [w:] Ochrona praw mniejszości narodowych i religijnych, pod red. Z. Hołda, Lublin 1993, s. 22-30.
} 
stanowisko wśród równouprawnionych wyznańn ${ }^{17}$. Artykuł 115 dał uznanym mniejszościom i związkom religijnym możliwość rządzenia się własnymi ustawami, których państwo uznania nie odmówiło z powodu sprzeczności z polskim prawem. Stosunek państwa do uznawanych Kościołów i wyznań miał zostać ustalony na drodze ustawowej ${ }^{18}$. Artykuł 116 dotyczył związków religijnych prawnie nieuznanych. Państwo miało je uznać, o ile organizacja, nauka i ustrój tego związku nie będą sprzeczne z porządkiem publicznym ${ }^{19}$. W wyżej podanych artykułach widoczny jest podział na związki wyznaniowe uznane i nieuznane przez państwo. Samo uznanie prawne istniejącego wyznania nie wymagało ustawy, a zatem mogło być dokonane rozporządzeniem właściwego ministra ${ }^{20}$. Sytuacja prawna wszystkich uznanych związków wyznaniowych, oprócz Kościoła rzymskokatolickiego, miała zostać uregulowana za pomocą ustawy.

W świetle konstytucji marcowej Kościół prawosławny w Polsce należał do wyznań uznanych przez państwo, ale które nie posiadały unormowanego położenia prawnego ${ }^{21}$. Na status Kościoła prawosławnego w II Rzeczypospolitej wpływ miały postanowienia traktatu ryskiego z $1921 \mathrm{r}$. Oba państwa podpisujące traktat zobowiązały się nie mieszać „do spraw ustroju i życia Kościołów i związków wyznaniowych znajdujących się na terytorium drugiej strony". W ten sposób władze polskie uzyskały prawo do kontroli nad Kościołem prawosławnym w swym kraju i wprowadzenia autokefaliii ${ }^{22}$.

Władze polskie chciały we własnym zakresie znaleźć osobę, która pokierowałaby organizacją naczelnych władz Kościoła prawosławnego na terytorium Rzeczypospolitej. W tym celu Ministerstwo Wyznań Religijnych i Oświecenia Publicznego (dalej: MWRiOP) i komisariat Ziem Wschodnich zwołali 24 maja 1920 r. w Wilnie naradę z przedstawicielami społeczności prawosławnej z biskupami Włodzimierzem i Eleuteriuszem na czele. Na mocy podjętych ustaleń MWRiOP zarząd nad diecezjami warszawską i chełmską oraz organizację aparatu kościelnego powierzyło biskupowi białostockiemu Włodzimierzowi (Tichonickiemu) ${ }^{23}$. Do pomocy władyce powołano radę

\footnotetext{
17 M. T. Staszewski, Wolność sumienia..., s. 119-120. Kościół rzymskokatolicki uzyskał uprawnienia jakich nie posiadał żaden inny związek wyznaniowy. Mógł on rządzić się własnymi prawami, a po zawarciu 10 lutego 1925 r. konkordatu ze Stolicą Apostolską państwo zupełnie straciło kontrolę nad Kościołem. S. Żeleźniakowicz, Z historii..., „WPAKP” 1981, nr 4, s. 44.

18 H. E. Wyczawski, Cerkiew prawosławna w II Rzeczypospolitej, [w:] Kościót w II Rzeczypospolitej, Lublin 1980, s. 167; J. Drobosz, Prawne aspekty sytuacji Kościotów i zwiqzków wyznaniowych w II Rzeczypospolitej, „Chrześcijanin a współczesność”, 1986, nr 6, s. 17.

19 M. T. Staszewski, Wolność sumienia..., s. 119.

20 H. Świątkowski, Niektóre aspekty prawne stosunku państwa do wyznań w Polsce przedwrześniowej, „Państwo i Prawo” 1959, nr 1, s. 29-30; M. T. Staszewski, Mniejszości wyznaniowe w II Rzeczypospolitej, ,Zeszyty Argumentów" 1967, nr 3, s. 75.

21 M. Papierzyńska-Turek, Między tradycją..., s. 136.

22 H. E. Wyczawski, Cerkiew prawosławna, [w:] Historia Kościoła w Polsce, pod red. B. Kumora i Z. Obertyńskiego, t. II, cz. 2, Poznań Warszawa 1979 , s. 88

23 Алексий (Громадский) архиепископ, К истории Православной Церкви в Польше.., с. 8; М. Papierzyńska-Turek, Problem autokefalii
}

doradczą złożoną z trzech duchownych i dwóch świeckich przedstawicieli społeczności prawosławnej. Biskup Włodzimierz prowadził samodzielną politykę i znacznie rozszerzył swoje kompetencje. Władyka utrzymywał kontakty z patriarchatem moskiewskim i wziął udział w konsekracji biskupa Sergiusza (Korolowa), pozostającego w jurysdykcji patriarchy Tichona. Z polecenia patriarchy 4 kwietnia 1921 r. archimandryta Sergiusz został wyświęcony na biskupa bielskiego. Patriarcha powierzył mu zarząd nad diecezją chełmską. Postanowienia patriarchy nie uznały władze państwowe. W tej sytuacji władyka zmuszony został do pobytu w klasztorze św. Onufrego w Jabłecznej $^{24}$. Za działania sprzeczne z polityką rządu biskup Włodzimierz został odsunięty od spraw organizacji władzy i życia cerkiewnego. W tej sytuacji w lipcu 1921 r. biskupowi krzemienieckiemu Dionizemu (Waledyńskiemu) zaproponowano opracowanie projektu organizacji władz centralnych ${ }^{25}$. Władze państwowe obiecały władyce powołanie go na najwyższe stanowisko w Kościele prawosławnym w Polsce. Biskup Dionizy przyjął propozycję władz państwowych ${ }^{26}$. Pierwszym sukcesem władyki Dionizego było uzyskanie zgody MWRiOP na utworzenie seminarium duchownego. Hierarcha objął też zarząd nad eparchia wołyńską. Biskup podjął starania o przyjazd do kraju przebywającego we Włoszech arcybiskupa Jerzego (Jaroszewskiego), który zdaniem władz rokował największe nadzieje na zgodną współpracę z rządem polskim ${ }^{27}$.

Arcybiskup przybył do Polski na zaproszenie władz państwowych w sierpniu 1921 r. i objął po biskupie Włodzimierzu diecezje warszawską i chełmską ${ }^{28}$. Biskup białostocki Włodzimierz pozostał jedynie administratorem eparchii grodzieńskiej. Nieco wcześniej do Wilna w 1919 r.

Kościoła Prawosławnego w Polsce w latach 1918-1939, „Euhemer Przegląd Religioznawczy" 1980, nr 1, s. 56.

24 S. Kiryłowicz, Z dziejów prawosławia w II Rzeczypospolitej Polskiej. Niektóre problemy na tle polityki wyznaniowej państwa w 1918-1939, „WPAKP”, 1986, nr 2, s. 41. Patriarcha w kwietniu 1922 r. wydzielił Chełmszczyznę z diecezji warszawskiej i wyznaczył jej zarządcą biskupa Sergiusza. Bp Sergiusz faktycznie nie objął swojej diecezji i jako nieuznawany przez władze państwowe nie uczestniczył w posiedzeniach soborów. 8 maja 1922 r. ,za działalność polityczną nie mającą żadnego związku z działalnością duchowną" został pod eskortą deportowany do Czechosłowacji. S. Żeleźniakowicz, Z historii..., „WPAKP” 1982, nr 3/4, s. 14-15.

25 Алексий (Громадский) архиепископ, К истории Православной Церкви в Польше..., с. 9; М. Papierzyńska-Turek, Kościół prawosławny $w$ Polsce $w$ latach 1918-1927. Sytuacja prawna i konflikty wewnętrzne, „Dzieje Najnowsze” 1976, nr 3, s. 17.

26 S. Stępień, Główne nurty życia religijnego spoleczności ukraińskiej w Drugiej Rzeczypospolitej, „Slavia Orientalis” 1990, $\mathrm{nr} 1 / 2$, s. 120; M. Bendza, Autokefalia Kościoła prawosławnego w Polsce, „Е $\Lambda \Pi І \Sigma ”$, R. V (XVII), z. 7-8 (20-21), 2003, s. 121; A. Mironowicz, Kościót prawosławny na ziemiach polskich $w$ XIX i XX wieku, s. 87-88.

27 M. Papierzyńska-Turek, Problem autokefalii..., s. 56. Arcybiskup Jerzy były biskupem mińskim i rektorem Akademii Teologicznej w Petersburgu. Władyka wyjechał z Rosji jako arcybiskup charkowski. Najpierw przebywał w Jugosławii, a później został mianowany administratorem Kościoła prawosławnego we Włoszech i osiadł w Bari, skąd przybył do Polski. Abp Jerzy złożył pisemne zobowiązanie rządowi polskiemu, że nie pozwoli sobie na występowanie przeciw Polsce i będzie popierał starania o ustanowienie autokefalii Cerkwi prawosławnej w Polsce. S. Żeleźniakowicz, Z historii..., „WPAKP”, 1982, nr 2, s. 14.

28 A. Friszke, Kościoły wschodnie..., s. 84. 
przybył biskup dyneburski Pantelejmon (Paweł Rożnowski) wyznaczony przez patriarchę moskiewskiego Tichona na katedrę nowo utworzonej diecezji pińsko-nowogródzkiej $^{29}$. Władyka objął katedrę poleską dopiero 23 października 1920 r. po zakończeniu działań wojennych na froncie wschodnim $^{30}$. Rząd polski podjął rozmowy z biskupami Jerzym, Dionizym i Pantelejmonem. Wymienieni władycy 16 września 1921 r. zostali zaproszeni na konferencję u ministra WRiOP Macieja Rataja. Na konferencji ustalono, że naczelna władza w Kościele prawosławnym w Rzeczypospolitej zostanie powierzona, zgodnie z zamierzeniami, arcybiskupowi Jerzemu, a biskupi złożyli oświadczenie o chęci współpracy z rządem i „pracy na korzyść Cerkwi na podstawie autokefalii”. Biskupi swoją decyzję uzależnili od otrzymania na takie rozwiązanie błogosławieństwa patriarchy moskiewskiego Tichona. W tej sprawie wystosowano do patriarchy specjalne posłanie ${ }^{31}$.

Na prośbę biskupów, popartą staraniami rządu na drodze dyplomatycznej za pośrednictwem przedstawiciela polskiego w Moskwie Tytusa Filipowicza, patriarcha Tichon dekretem z 28 września 1921 r. mianował arcybiskupa Jerzego (Jaroszewskiego) czasowym administratorem diecezji warszawskiej i chełmskiej oraz nadał mu godność egzarchy patriarszego $\mathrm{w}$ Polsce na prawach metropolity prowincjonalnego ${ }^{32}$. Kościół prawosławny uzyskał w ten sposób szeroką autonomię i zarząd składający się z Soboru Biskupów na czele z egzarchą jako przewodniczącym ${ }^{33}$. Wyznaczony w 1918 r. na metropolitę warszawskiego arcybiskup Serafin złożył prośbę do Synodu Rosyjskiego Kościoła Prawosławnego o zwolnienie go z funkcji biskupa diecezji warszawskiej. Moskiewski Synod 30 stycznia 1922 r. zwolnił arcybiskupa Serafina z zajmowanej funkcji, mianując na jego miejsce egzarchę Jerzego. Abp Jerzy został wyniesiony do godności metropolity warszawskie-

\footnotetext{
29 А. Свитич, Православная Церковь в Польше и ее автокефалия, c. 97. Diecezja pińsko-nowogródzka powstała z diecezji mińskiej, której trzon pozostał poza granicami Polski. Por.: J. S. Langrod, O autokefalii..., s. 66-67.

30 Н. Дорош, Православный Гродно, Гродно, 2000, с. 182-187; tenże, Митрополит Пантелеимон (Рожновский 1867-1950), „Беларускі Праваслаӱны Каляндар" на 2003 год, Мінск 2002, с. 135. М. В. Шкаровский, Начистская Германия и Православная Церковь (начистская политика в отношении Православной Церкви и религиозное возрождение на территории СССР), Москва 2002, с. 516-517.

31 А. Свитич, Православная Церковь в Польше и ее автокефалия, c. 97; M. Papierzyńska-Turek, Między tradycja a rzeczywistościa. Państwo wobec prawosławia 1918-1939, Warszawa 1989, s. 106.

32 J. S. Langrod, O autokefalii..., s. 69; A. Borkowski, Miedzy Konstantynopolem a Moskwą. Źródła do dziejów autokefalii Kościoła prawosławnego w Rzeczypospolitej (1919-1927), Białystok 2015, s. 26-29.

33 M. Zyzykin, Autokefalia i zasady jej zastosowania, Warszawa 1931, s. 59; A. Friszke, Kościoły wschodnie..., s. 84. Patriarcha Tichon oświadczał w tym samym czasie, że nie może udzielić autokefalii albowiem ,święte kanony nie pozwalają udzielić autokefalii różnoplemiennym prawosławnym, którzy zamieszkują w granicach państwa polskiego w charakterze narodowych i religijnych mniejszości". W rozmowie z polskim posłem oświadczył natomiast, że jego sprzeciw w sprawie autokefalii podyktowany jest brakiem możliwości zwołania soboru przedstawicieli duchowieństwa i świeckich, co utrudnia formalne załatwienie sprawy. О. Ф. Купранець, Православна цеекка в міжвоєнній Польщі, 1918-1939, „Analecta OSBM”, vol. XXXI, Рим 1974, c. 15; M. Papierzyńska-Turek, Problem autokefalii..., s. 58; M. Zyzykin, Autokefalia..., s. 101.
}

go z prawem noszenia białego kłobuka z krzyżem i mitry z krzyżem. Synod powierzył mu zarazem czasowy zarząd nad diecezją chełmską ${ }^{34}$. Synod Rosyjskiego Kościoła Prawosławnego aprobował ponadto statut Kościoła prawosławnego w Polsce ${ }^{35}$.

Statut został przesłany na ręce metropolity Jerzego $\mathrm{z}$ zaznaczeniem, że staje się on prawomocny $\mathrm{z}$ chwilą udzielenia na niego zgody ze strony rządu polskiego. Rząd polski odmówił jego przyjęcia, a tekst dokumentu zwrócił metropolicie Jerzemu ${ }^{36}$. Jednym z motywów odmowy był przewidywany w statucie ścisły związek hierarchiczny episkopatu polskiego z patriarchatem moskiewskim, czego rząd polski, dążący do uzyskania samodzielności dla Kościoła prawosławnego w Polsce, sobie nie życzył. Przyjęty przez Synod Rosyjskiego Kościoła Prawosławnego status nie sprzyjał ustanowieniu autokefalii Kościoła prawosławnego w Polsce.

W latach 1918-1922 w granice państwa polskiego powróciła znaczna część ewakuowanego w 1915 r. duchowieństwa prawosławnego. Zmiany polityczne w Rosji Radzieckiej spowodowały przybycie do Polski wielu duchownych, którzy nigdy nie byli na jej terytorium. W tej sytuacji Ministerstwo Spraw Wewnętrznych 8 czerwca 1921 r. wydało okólnik O polskim obywatelstwie, o prawie azylu i zasadach pobytu czasowego na terenie Polski, który ograniczał napływ duchowieństwa rosyjskiego. Okólnik ze względów humanitarnych określał, że prawo do pobytu i obywatelstwa mają osoby, które przed wojną mieszkały na terenach polskich i aktualnie wykazują swoją lojalność wobec władz państwowych. Prawo pobytu czasowego dostawały tylko osoby, którym powrót do Rosji Radzieckiej groził poważniejszymi konsekwencjami, a ich obecność na terenie Polski nie zagrażała bezpieczeństwu państwa. Na podstawie tego okólnika władze administracyjne mogły usuwać z terytorium państwa osoby uważane przez nich za niepożądane. Według sprawozdania MWRiOP w $1923 \mathrm{r}$. z terenu województwa białostockiego z 16 przybyłych usunięto jednego duchownego, $\mathrm{z}$ terenu województwa lubelskiego na 19 przybyłych 14 otrzymało obywatelstwo polskie. Z kolei Urząd Delegata Rządu w Wilnie w 1922 r. donosił, że zgodnie z obowiązującym prawem będzie wysiedlać z granic państwa polskiego wszystkich duchownych prawosławnych, którzy przybyli do Polski w sposób nielegalny ${ }^{37}$.

Pierwsze próby uregulowania sytuacji Kościoła prawosławnego nastąpiły w styczniu $1922 \mathrm{r}$. Na zwołanym przez metropolitę Jerzego pierwszym Soborze Biskupów

\footnotetext{
34 А. Свитич, Православная Церковь в Польше и ее автокефалия, s. 100. W liście z 24 marca 1925 r. patriarcha Tichon stwierdził, że abp Jerzy nie był metropolitą całej Polski a tylko warszawskim i chełmskim, albowiem przysłany przez Synod moskiewski projekt statutu prawosławnego Kościoła w Polsce nie został przez rząd polski przyjęty. Tamże, s. 100101. Алексий (Громадский) архиепископ, К истории Православной Церкви в Польше..., s. 17.

35 Нацыянальны гістарычы архів Беларусі w Mińsku (dalej: НГАБ), ф. 325, оп. 1, нр. 128, к. 71; A. Mironowicz, Kościól prawosławny w Polsce, s. 520-521.

36 M. Zyzykin, Autokefalia..., s. 59.

37 AAN, MWRiOP, nr 381, k. 14; nr 416, k. 5; nr 131
} 
w dniach 24-30 stycznia 1922 r. omówiono problem unormowania stosunków między państwem a Kościołem prawosławnym. W soborze wzięli udział metropolita Jerzy oraz biskupi Dionizy i Pantelejmon. Biskup białostocki i grodzieński Włodzimierz nie przyjechał do Warszawy usprawiedliwiając się chorobą. Na obrady soboru przybyli przedstawiciele rządu z dyrektorem departamentu wyznań Stanisławem Piekarskim na czele ${ }^{38}$. Podczas soboru rozpatrzono przedłożony tekst umowy o stosunku państwa do Kościoła prawosławnego w Polsce w dwóch redakcjach rządowej i egzarszej ${ }^{39}$. Po naniesieniu poprawek, składających się z niektórych zapisów statutu nadesłanego z Moskwy, na wyraźne życzenie metropolity Jerzego projekt Tymczasowych przepisów został 28 stycznia 1922 r. przedłożony do podpisu uczestnikom Soboru ${ }^{40}$. Biskupi Włodzimierz i Pantelejmon odmówili podpisania przepisów, motywując brakiem na nie zgody patriarchy, niezgodnością szeregu zapisów z prawem kanonicznym i konstytucją. Według hierarchów Tymczasowe przepisy uzależniały Kościół prawosławny od państwa.

W sytuacji braku pełnego porozumienia się z biskupami prawosławnymi projekt rządowy, $\mathrm{z}$ naniesionymi w czasie pertraktacji poprawkami, został 30 stycznia 1922 r. podpisany przez ministra WRiOP Antoniego Ponikowskiego. Minister Ponikowski 23 lutego 1922 r. powiadomił biskupów i wojewodów o treści Tymczasowych przepisów o stosunku rządu do Kościoła prawosławnego $w$ Polsce i ogłosił, że ustalone w tym rozporządzeniu zasady mają od dnia ogłoszenia moc obowiązującą ${ }^{41}$. Tymczasowe przepisy były pomyślane jako prowizoryczna norma prawna, która miała zaspokoić doraźne potrzeby Kościoła prawosławnego w Polsce. Dowodem takiego rozumienia tego dokumentu jest wstęp do przepisów: „Celem ujednolicenia trybu postępowania w sprawach Kościoła prawosławnego na obszarze Rzeczypospolitej Polskiej, Rząd w osobie ministra WRiOP na czas przejściowy do chwili uchwalenia ustawy, normującej stosunek Państwa Polskiego do Kościoła Prawosławnego zgodnie z wymogami art. 115 Ustawy Konstytucyjnej z dnia 17 marca 1921 r., ustala następujące zasady (...)"»2

Zasady te miały przetrwać wiele lat stwarzając podstawę prawną do działalności administracji państwowej $\mathrm{w}$ stosunku do prawosławia w Polsce. Tymczasowe przepisy z prawnego punktu widzenia wzbudzały powszechną krytykę. Prawnicy uważali, że Tymczasowe przepisy nie mogą być aktem regulującym stosunek państwa do tego Kościoła, gdyż akt prawnego uznania wymagałby ustawy, na co wskazuje i artykuł 115 konstytucji marcowej i artykuł 3 ust. 5 tejże konstytucji mówiący, że „rozporządzenia władzy, z których wynikają prawa lub obowiązki obywa-

\footnotetext{
38 S. Żeleźniakowicz, Z historii..., „WPAKP” 1982, nr 2, s. 17-18.

39 Алексий (Громадский) архиепископ, К истории Православной Церкви в Польше..., с. 15 .

${ }_{40}$ M. Zyzykin, Autokefalia..., s. 59; А. Свитич, Православная Церковь в Польше и ее автокефалия, с. 101-103; Алексий (Громадский) архиепископ, К истории Православной Церкви в Польше..., с. 15-16. ${ }^{4}$ S. Żeleźniakowicz, Z historii..., „WPAKP” 1982, nr 2, s. 18-19; Z. Urbański, Mniejszości narodowe w Polsce, Warszawa 1933, s. 329.

42 J. S. Langrod, $O$ autokefalii..., s. 75.
}

teli, mają moc obowiązującą tylko wtedy, gdy zostały wydane $\mathrm{z}$ upoważnienia ustawy i z powołania się na nią"43. Również władze państwowe odnosiły się z rezerwą do wydanego dokumentu. Premier Władysław Grabski, uznając brak podstaw prawnych rozporządzenia z 30 stycznia 1922 r., wyjaśniał: „Względy politycznej i faktycznej natury spowodowały jednak rząd do ogłoszenia rozporządzenia, względy te dokładnie rozważone, nakazywały stworzyć pewien modus vivendi w stosunkach rządu z Kościołem prawosławnym i uregulować te stosunki przejściowo do czasu ustawy, jak wymaga art. 115, ust. 2. Przepisy te mimo formalnego nie wprowadzenia stanowią faktyczną podstawę do wzajemnych stosunków organów administracyjnych z Kościołem prawosławnym”44.

Tymczasowe przepisy regulowały kwestie prawno -ustrojowe Kościoła prawosławnego a w szczególności reprezentacji prawnej Kościoła, kompetencji metropolity, biskupów i instytucji kanonicznych, kwestię językową w Kościele, organizacji konsystorzy duchownych, zjazdów dekanalnych, diecezjalnych i Soboru Generalnego oraz sprawę podziału terytorialnego poszczególnych diecezji. Ponadto akt ten określał sytuację konstytucyjną Kościoła prawosławnego w Polsce, funkcjonowanie bractw cerkiewnych, uposażenia i edukację duchowieństwa ${ }^{45}$.

Odmowa podpisania Tymczasowych przepisów przez biskupa Pantelejmona spowodowała, że ministerstwo w porozumieniu z metropolią cofnęło mu zgodę na wykonywanie jurysdykcji w diecezji pińsko-nowogródzkiej i tymczasowy zarząd nad biskupstwem powierzyło metropolicie Jerzemu. Biskup Pantelejmon został zmuszony do zamieszkania w klasztorze w Mielcu ${ }^{46}$. Za sprzeciw wobec autokefalii przebywający w monasterze w Jabłecznej biskup bielski Sergiusz został wydalony do Czechosłowacji. $\mathrm{W}$ tej sytuacji władyka Włodzimierz po początkowych wahaniach ostatecznie zaakceptował treść przepisów, czego wyrazem było wydrukowanie treści Tymczasowych przepisów w jego diecezjalnej prasie - „Гродненских епархиальных ведомостях" ${ }^{\text {"47 }}$. Pomimo protestów części duchowieństwa rząd uznał stanowisko metropolity za wystarczające i ogłosił Tymczasowe przepisy o stosunku rządu do Kościoła prawostawnego w Polsce jako czasową normę regulującą stosunek państwa do Kościoła prawosławnego $\mathrm{w}$ formie rozporządzenia ministra WRiOP opublikowanego w „Monitorze Polskim” z dnia 16 lutego 1922 r. oraz w „Dzienniku Urzędowym MWRiOP”48.

Wątpliwości wobec prawnego statusu Kościoła prawosławnego miało Ministerstwo Sprawiedliwości, które 5 listopada 1924 r. w piśmie do MWRiOP stwierdziło: „Mi-

\footnotetext{
43 Tamże, s. 76; J. Sawicki, Studia nad położeniem..., s. 258-259; M. Papierzyńska-Turek, Kościół prawosławny..., s. 20-21, przyp. 20.

44 K. Krasowski, Zwiąki wyznaniowe..., s. 120-121; M. Winiarczyk -Kossakowska, Ustawy III Rzeczypospolitej o stosunku państwa do Kościołów chrześcijańskich, Warszawa 2004, s. 68-69.

45 J. S. Langrod, $O$ autokefalii..., s. $72-77$.

46 S. Żeleźniakowicz, Z historii..., „WPAKP” 1982, nr 2, s. 18.

47 M. Papierzyńska-Turek, Między tradycja..., s. 142.

48 J. S. Langrod, O Autokefalii..., s. 71; A. Mironowicz, Kościót prawosławny na ziemiach polskich $w$ XIX $i$ XX wieku, s. 91-92; tenże, Kosciót prawosławny $w$ Polsce, s. 522-523.
} 
nisterstwo Sprawiedliwości ma zasadnicze zastrzeżenia co do mocy obowiązującej Tymczasowych przepisów o stosunku Rzadu do Kościoła Prawosławnego w Polsce"49. Wymienione wątpliwości nie przeszkodziły MWRiOP w wydaniu 21 października 1924 r. decyzji o rozszerzeniu mocy prawnej Tymczasowych przepisów na diecezję wileńską $^{50}$. Sytuacja prawna Kościoła prawosławnego była niestabilna, albowiem wszedł w życie akt, który powszechnie był podważany, a w którego moc wątpił nawet sam rząd. Tymczasowe przepisy regulowały zasady funkcjonowania Kościoła. Za reprezentację prawną Kościoła prawosławnego w Polsce uznany został Sobór Biskupów. Dla prawomocności uchwał wystarczała zgoda egzarchy (metropolity) i dwóch biskupów diecezjalnych. Egzarsze zezwolono na wykonywanie jurysdykcji kanonicznej i metropolitalnej w granicach byłej diecezji warszawsko-chełmskiej. Metropolicie zezwolono na mianowanie, przenoszenie i usuwanie biskupów w całym państwie, ale po uprzednim uzgodnieniem z rządem. Wszyscy biskupi zostali zobowiązani do składania przysięgi na wierność państwu polskiemu. Władza biskupa sprowadzała się do mianowania i usuwania proboszczów. Wojewoda mógł w ciągu dwóch miesięcy głosić swoje zastrzeżenia co do podjętej przez biskupa decyzji. O usunięciu lub przeniesieniu proboszcza biskup powinien zawiadomić starostę, a ten wiadomość tę przekazać wojewodzie. Minister MWRiOP miał prawo zażądać od właściwego biskupa natychmiastowego usunięcia duchownego, jeżeli ten utracił obywatelstwo polskie, dokonał zbrodni, popełnił czyn uwłaczający moralności lub był szkodliwy interesom państwa. Kandydat na proboszcza zanim objął po raz pierwszy parafię zobowiązany był złożyć przysięgę na wierność państwu. Akty stanu cywilnego i inne dokumenty miały być prowadzone w języku polskim. W stosunku do władz państwowych i samorządowych biskupi powinni byli posługiwać się wyłącznie językiem polskim jako urzędowym. Język polski miał być obowiązkowo wykładany w seminariach duchownych.

Tymczasowe przepisy uznawały konsystorze duchowne w Warszawie, Krzemieńcu, Grodnie, Pińsku i w Wilnie. Zjazdy dekanalne odbywać się mogły po uprzednim zawiadomieniu właściwego starosty, a zjazdy diecezjalne po uprzednim zawiadomieniu właściwego wojewody. Sobory Generalne z udziałem laikatu zwoływał egzarcha za każdorazową uprzednią zgodą ministra WRiOP w składzie zatwierdzonym przez Sobór Biskupów. Tworzenie nowych stanowisk biskupów diecezjalnych i biskupów wikariuszy uzależnione było od zgody rządu. Zmiany terytorialne diecezji i parafii nie mogły być dokonywane bez uprzedniego porozumienia się z ministrem WRiOP. Wizytacje pasterskie powinny być uzgadniane $\mathrm{z}$ administracją rządową. Rząd, w myśl artykułów 111 i 113 konstytucji, zagwarantował ludności prawosławnej wolność publicznego odprawiania nabożeństw i wykonywania praktyk religijnych. Nauka religii dla uczniów prawosławnych w szkołach publicznych była obowiązkowa i miała być wykładana w ję-

\footnotetext{
49 S. Żeleźniakowicz, Z historii..., „WPAKP” 1982, nr 2, s. 19

50 M. Papierzyńska-Turek, Między tradycją..., s. 142.
}

zyku ojczystym uczniów. Zezwolono na zakładanie bractw cerkiewnych, a ich statut podlegał zatwierdzeniu ministra WRiOP. Do czasu uregulowania w drodze ustawy sprawy uposażenia duchownych prawosławnych skarb państwa wypłacał diecezjalnym biskupom i konsystorzom pobory. Biskupi wikariusze nie otrzymywali od skarbu państwa uposażenia. Wychowanie kandydatów na kapłanów należało do seminariów duchownych uznanych przez rząd. Program nauczania w seminarium podlegał zatwierdzeniu przez ministra WRiOP, który ponadto opiniował kandydatów na profesorów seminariów, wyznaczonych przez Sobór Biskupów. Kapłanem mógł zostać absolwent zagranicznych studiów teologicznych pod warunkiem uzyskania obywatelstwa polskiego i zgody państwa ${ }^{51}$.

Tymczasowe przepisy pozwalały władzom zachować pełną kontrolę nad sprawami organizacyjnymi i personalnymi Kościoła prawosławnego. Przepisy zmuszały duchowieństwo do zachowania całkowitej lojalności wobec administracji państwowej. W ustroju cerkiewnym przyjęto zasady synodalno-konsystorskie, usuwając w ten sposób znaczenie czynnika świeckiego, co ułatwiło kierowaniem Kościołem i zacieśniało jego więź z państwem. W tym akcie prawnym pominięto istotne sprawy dla Kościoła prawosławnego, takie jak np. osobowość prawna, majątek Kościoła, liczbę parafii, uposażenie duchowieństwa, przesuwając rozstrzygnięcie tych spraw na czas nieokreślony. Stopień wolności życia wewnętrznego Kościoła prawosławnego w praktyce zależał od przedstawicieli administracji państwowej, począwszy od starosty, a skończywszy na ministrze WRiOP ${ }^{52}$.

Tymczasowe przepisy nie były ustawą i z tego powodu nie mogły znieść ustaw byłego Cesarstwa Rosyjskiego. W rezultacie, aż do prawnego unormowania ustroju wewnętrznego i organizacji Kościoła prawosławnego w Polsce w drodze własnej ustawy, obowiązywały w dalszym ciągu, obok prawa kanonicznego Kościoła prawosławnego, również przepisy prawne wydane przed 1917 r. przez państwo rosyjskie dotyczące położenia prawnego, ustroju i duchowieństwa tego Kościoła. Przepisy te stosowano, jeżeli nie pozostawały one w sprzeczności z ustawodawstwem polskim ${ }^{53}$. W ten sposób Kościół prawosławny w Polsce uzyskał osobowość prawną i mógł występować przed sądami w spornych sprawach, np. majątkowych ${ }^{54}$. Tymczasowe przepisy stały się wbrew nazwie i intencji władz jedyną podstawą prawną stosunku państwa do Cerkwi przez cały okres międzywojenny. Ostateczne uregulo-

J. S. Langrod. O Autokefalii..., s. 72-75; H. E. Wyczawski, Cerkiew prawostawna..., s. 167.

52 A. Friszke, Kościoly wschodnie..., s. 148; A. Mironowicz, Kościót prawosławny na ziemiach polskich $w$ XIX i XX wieku, s. 92-94; tenże, Kościót prawosławny w Polsce, s. 524-525.

53 J. Sawicki, Studia nad położeniem..., s. 261; J. S. Langrod, $O$ autokefalii..., s. 102-104. Źródła prawa kościelnego obowiązujące w Kościele prawosławnym w okresie międzywojennym por.: H. Świątkowski, Wyznania religijne $w$ Polsce ze szczególnym uwzględnieniem ich stanu prawnego, s. 147, przyp. 55. Przepisy rosyjskie Kościoła prawosławnego, przyp. 56; M. Papierzyńska-Turek, Między tradycją..., s. 149-150.

54 J. Sawicki, Studia nad położeniem..., s. 262-264; H. Świątkowski, Wyznania religijne..., s. 149-150. 
wanie statusu Kościoła prawosławnego w Polsce nastąpiło dopiero w $1938 \mathrm{r} .^{55}$ Tymczasowe przepisy stanowiły ważny etap na drodze do autokefalii. Doniosłe znaczenie miał fakt uznania w tym akcie Soboru Biskupów za prawną reprezentację Kościoła prawosławnego, który w sprzyjających warunkach mógłby przeprowadzić uchwałę o autokefalii ${ }^{56}$.

Realizacja zamierzeń rządowych w sprawie autokefalii była możliwa do przeprowadzenia po aresztowaniu w maju 1922 r. przez władze radzieckie patriarchy Tichona. Jego miejsce zajęli przedstawiciele tzw. „Żywej Cerkwi”, którzy utworzyli Komitet Cerkiewny wyrażający chęć współpracy z bolszewikami ${ }^{57}$. W związku z zaistniałą sytuacją, na mocy dekretu patriarchy moskiewskiego Tichona i Synodu Rosyjskiego Kościoła Prawosławnego z 1 listopada 1920 r. o postępowaniu w wypadku niemożności utrzymywania normalnych stosunków z moskiewską władzą kościelną, metropolita Jerzy zwołał 30 maja 1922 r. Sobór Biskupów w Lawrze Poczajowskiej ${ }^{58}$. W obradach soboru uczestniczyli metropolita Jerzy, biskup krzemieniecki Dionizy, biskup grodzieński Włodzimierz oraz biskup nowo przyłączonej diecezji wileńskiej Eleuteriusz ${ }^{59}$. Sobór ten w zamierzeniach metropolity miał być początkiem drogi do autokefalii. Metropolita Jerzy przedstawił projekt uchwały, w której sobór stwierdził, że „wszystkie sprawy powołane okolicznościami rozwiązywać będzie na miejscu i nie będzie przyjmować żadnych zarządzeń od Komitetu Kościelnego w Moskwie"60. Biskupi Eleuteriusz i Włodzimierz chcieli wnieść poprawki do uchwały mówiące o konieczności zwołania lokalnego soboru, który zdecydowałby o dalszych losach Cerkwi w Polsce i żądali jednomyślności przy decydowaniu w sprawach, które w normalnych warunkach są $\mathrm{w}$ dyspozycji patriarchy i synodu ${ }^{61}$. Gdy ich wnioski zostały odrzucone, obaj hierarchowie opuścili obrady. Uchwała soboru została przyjęta, bez głosowania, przez metropolitę Jerzego i biskupa Dionizego. W celu wzmocnienia strony prorządowej i ważności uchwały 4 czerwca 1922 r. na biskupa wyświęcono archimandrytę Aleksandra (Mikołaja Inoziemcowa)

\footnotetext{
S. Stępień, Glówne nurty..., s. 120.

56 K. Krasowski, Związki wyznaniowe..., s. 120-121.

57 J. S. Langrod, O Autokefalii..., s. 52-53; K. Krasowski, Zwiazki wyznaniowe..., s. 122; H. Papierzyńska-Turek, Problem autokefalii..., s. 59; Н. А. Кривова, Власть и иерковь в 1922 - 1925 гг.: Политбюро и ГПУ в борьбе за иерковные ченности и политическое подчинение духовенства, Москва 1997, с. 220-221; A. Mironowicz, Cerkiew prawosławna $w$ dawnej $i$ we współczesnej Rosji, [w:] Bizancjum - Prawosławie-Romantyzm. Tradycja wschodnia w kulturze XIX wieku, pod red. J. Ławskiego i K. Korotkicha, Białystok 2004, s. 65.

58 M. Zyzykin, Autokefalia..., s. 60; A. Friszke, Kościoły wschodnie..., s. 86; 18 czerwca 1922 r. metropolita jarosławski Agafangel, jako zastępca tronu patriarszego, wydał list pasterski, w którym nawiązał do aktu autonomii diecezjalnej Tichona z 1920 r. i nadał wszystkim biskupom prawosławnym prawo samodzielnego zarządu diecezjami do czasu uwolnienia patriarchy z niewoli bolszewickiej. J. S. Langrod, O Autokefalii..., s. 53.

59 M. Papierzyńska-Turek, Między tradycją..., s. 111. W soborze nie wziął udziału biskup Pantelejmon. Władyka w tym czasie przebywał w klasztorze w Mielcu.

60 Tamże, s. 111; A. Borkowski, Między Konstantynopolem a Moskwa, S. 33-34

61 А. Свитич, Православная Церковь в Польше и ее автокефалия, c. 104-105.
}

z tytułem władyki lubelskiego. Nowo wyświęconemu biskupowi 12 czerwca powierzono zarząd nad diecezją pińsko-nowogródzką, którą uprzednio odebrano władyce Pantelejmonowi ${ }^{62}$. Minister MWRiOP Kazimierz Kumaniecki zatwierdził bp. Aleksandra na ordynariusza diecezji pińsko-nowogródzkiej 21 sierpnia $1922 \mathrm{r}$.

Według Tymczasowych przepisów dla prawomocnej uchwały soboru wymagana była zgoda jedynie metropolity i dwóch biskupów. Metropolita Jerzy nieprzypadkowo wyświęcił na biskupa archimandrytę Aleksandra. Wymieniona trójka biskupów (Jerzy, Dionizy i Aleksander) będzie miała decydujący głos przy ogłoszeniu autokefalii i usunięciu z urzędów wszystkich oponentów. $Z$ uwagi na fakt, że rząd polski pragnął, aby przy tak ważnych decyzjach była jednomyślność episkopatu prawosławnego, metropolita Jerzy w czerwcu 1922 r. zwołał do Warszawy kolejny Sobór Biskupów ${ }^{63}$. W soborze uczestniczyły wszyscy uznawani przez władze biskupi. Obrady poprzedziło przemówienie prezesa Rady Ministrów Antoniego Ponikowskiego, w którym zawarto żądanie, ażeby ze względu na usunięcie władzy kanonicznej w Moskwie Sobór Biskupów przyjął uchwałę o samodzielności Kościoła prawosławnego w Polsce na zasadach autokefaliii ${ }^{64}$. Pod presją rządu Sobór Biskupów przyjął następujące postanowienia: we wszystkich sprawach dotyczących Kościoła prawosławnego w Polsce decydować ma Sobór Biskupów na miejscu, czyli Synod Kościoła prawosławnego w Polsce; Sobór Biskupów w Polsce nie będzie przyjmować żadnych rozporządzeń od utworzonego w Moskwie niekanonicznego zarządu kościelnego; członkowie Soboru Biskupów podejmą działania na rzecz ustanowienia autokefalii Kościoła prawosławnego w Polsce. Równocześnie zwrócono się do rządu z prośbą o wszczęcie starań u patriarchy konstantynopolitańskiego oraz innych patriarchów i głów autokefalicznych Kościołów mających na celu uzyskania błogosławieństwa na ustanowienie autokefalii ${ }^{65}$. Za uchwałą głosowali metropolita Jerzy, biskup Dionizy i biskup Aleksander. Hierarchowie ci, utworzyli Święty Synod, który 15 czerwca 1922 r. zatwierdził jego statut wewnętrzny ${ }^{66}$. Biskupi Eleuteriusz i Włodzimierz złożyli wobec wszystkich decyzji soboru votum separatum. Swój protest uzasadniali brakiem podstaw kanonicznych na ustanowienie autokefalii oraz sprzeciwem na nią patriarchy moskiewskiego, episkopatu i duchowieństwa prawosławnego w Polsce ${ }^{67}$.

Autokefalia miała zostać ogłoszona na podstawie Tymczasowych przepisów, ale nie była zgodna z prawem

62 J. S. Langrod, O Autokefalii..., s. 79; S. Żeleźniakowicz, Z historii..., „WPAKP” 1982, nr 1, s. 16; M. Papierzyńska-Turek, Między tradycją..., s. 111; K. Krasowski, Związki wyznaniowe..., s. 118.

63 А. Свитич, Православная Церковь в Польше и ее автокефалия, c. 106.

64 M. Zyzykin, Autokefalia..., s. 60; A. Borkowski, Między Konstantynopolem a Moskwa, s. 31-32, 34-36.

65 S. Żeleźniakowicz, Z historii..., „WPAKP” 1982, nr 3/4, s. 17; M. Zyzykin, Autokefalia..., s. 60-61; S. Kiryłowicz, Z dziejów prawosławia..., s. 50 .

66 A. Friszke, Kościoly wschodnie..., s. 86; M. Zyzykin, Autokefalia..., s. 61 .

${ }_{67}$ M. Papierzyńska-Turek, Kościół prawosławny..., s. 22; A. Mironowicz, Kościót prawosławny w Polsce, s. 527-528. 
kanonicznym. Brak podstaw kanonicznych do jej ogłoszenia stał się głównym argumentem wykorzystanym przez jej przeciwników. Kolejne miesiące 1922 r. były okresem wzmożonej walki zwolenników i przeciwników autokefalii. 30 czerwca odbył się zwołany przez biskupa Eleuteriusza zjazd diecezji wileńskiej, który potępił wprowadzenie autokefalii i odłączenie się od macierzystego Rosyjskiego Kościoła Prawosławnego. To samo uczynił zwołany 14-15 lipca 1922 r. zjazd diecezji grodzieńskiej. O swoim proteście postanowiono powiadomić możliwie wszystkie zainteresowane strony ${ }^{68}$.

W sytuacji zaognienia nastrojów wokół rewindykacji prawosławnych obiektów sakralnych rząd naciskał na Synod Biskupów w sprawie autokefalii. Członkowie Synodu, zamiast przeciwstawić się działaniom rewindykacyjnym, przystąpili do osłabienia przeciwników autokefalii. Synod zwołany przez metropolitę Jerzego we wrześniu 1922 r. pozbawił katedry biskupa Eleuteriusza, którego 13 października 1922 r. władze państwowe aresztowały i internowały w klasztorze kamedułów na Bielanach pod Krakowem. Po proteście złożonym przez rząd Litwy Kowieńskiej w Radzie Ligi Narodów biskup Eleuteriusz mógł wyjechać na Litwę, gdzie objął zarząd swej diecezji w granicach państwa litewskiego ${ }^{69}$. Na Synodzie 4 września 1922 r. do godności arcybiskupa podniesiono władykę krzemienieckiego i wołyńskiego Dionizego, a dzień wcześniej archimandrytę Aleksego (Aleksandra Gromadzkiego) wyświęcono mu na władykę wikarego z tytułem biskupa łuckiego. W ten sposób doszło do podziału diecezji litewsko-wileńskiej wzdłuż granic państwowych. Biskupstwem litewskim zarządzał na terytorium Republiki Litwy biskup Eleuteriusz. Z pozostałej części diecezji powstało władyctwo wileńsko-lidzkie. Do diecezji wileńsko-lidzkiej dodano trzy powiaty województwa nowogródzkiego. 25 września 1922 r. Sobór Biskupów poszerzył granice diecezji poleskiej (pińsko-nowogródzkiej) o powiaty brzeski, prużański, kobryński, drohicki i większą część kossowskiego należące poprzednio do eparchii grodzieńskiej ${ }^{70}$. Nazwę diecezji poleskiej (pińsko-nowogródzkiej) przemianowano na polesko-pińską. W skład tej diecezji weszły ziemie dawnej diecezji poleskiej (pińsko-nowogródzkiej) i część biskupstwa grodzieńskiego.

W 1922 r. nastapiła reorganizacja terytorialna diecezji prawosławnych. Władze cerkiewne zlikwidowały wówczas diecezję chełmską, włączając jej terytorium do eparchii metropolitalnej oraz dokonały zmian w strukturze terytorialnej i organizacyjnej w pozostałych biskupstwach. Ostatecznie pozostało pięć diecezji: warszawsko-chełmska, wołyńska, polesko-pińska, grodzieńsko-nowogródz-

\footnotetext{
68 А. Свитич, Православная Церковь в Польше и ее автокефалия, c. $115-117$.

69 J. S. Langrod, $O$ autokefalii..., s. 84-85; S. Żeleźniakowicz, $Z$ historii..., „WPAKP”, 1982, nr 3/4, s. 18.4 października 1924 r. patriarcha Tichon odznaczył biskupa Eleuteriusza brylantowym krzyżem na kłobuku, a biskupa Pantelejmona podniósł do godności arcybiskupa. Por.: K. Krasowski, Zwiazki wyznaniowe..., s. 123; M. Zyzykin, Autokefalia..., s. 61-62, przyp. 2; A. Borkowski, Między Konstantynopolem a Moskwa, s. $41-43$

70 J. S. Langrod, $O$ autokefalii..., s. 86.
}

ka, wileńsko-lidzka. Po ustaleniu wschodnich granic państwa polskiego zmienione zostały terytoria przedwojennych diecezji: litewsko-wileńskiej, mińskiej i żytomierskiej, których większa ich część pozostała po stronie Republiki Litewskiej i Rosji Radzieckiej ${ }^{71}$.

Podobny los do władyki Eleutoriusza spotkał biskupa Włodzimierza, który uchwałą Synodu z 12 października 1922 r. został zwolniony z kierowania diecezją grodzieńską i pozbawiony wikariatu białostockiego. Decyzją Synodu diecezję grodzieńską powierzono biskupowi łuckiemu Aleksemu. Na stałe miejsce pobytu władyce Włodzimierzowi wyznaczono klasztor prawosławny w Dermaniu na Wołyniu. Władyka Włodzimierz nie porzucił swojej dotychczasowej działalności, usiłując wspólnie z biskupem Pantelejmonem zorganizować w Polsce Kościół prawosławny zależny od patriarchatu moskiewskiego, za co dwa lata później został wysiedlony do Czechosłowacji ${ }^{72}$.

Powyższe decyzje Synod podjął pod wyraźną presją władz państwowych. Działania te zostały krytycznie ocenione przez Konstantego Srokowskiego, autora raportu o sytuacji narodowościowej na kresach wschodnich, przygotowanego na polecenie premiera Władysława Sikorskiego. „Sama sprawa autokefalii jako takiej nawet wśród prawosławnych nie stałaby źle, gdyby brano się do niej z większym taktem, umiarkowaniem, a przede wszystkim z większą znajomością kościelno-prawnej i kanonicznej strony zagadnienia. Niestety dotąd działano w tej trudnej i delikatnej sprawie nie systematycznie, ale w drodze nagłych wybuchów energii u poszczególnych ministrów, bez dokładnej znajomości strony zarówno prawnej, jak personalnej. Aresztowania biskupów, deportacje ich na Bielany pod Krakowem lub wysłanie do Czech czy na Litwę, mianowanie wreszcie i narzucenie nowych powolnych biskupów z pogwałceniem przepisów kanonicznych - to z pewnością najgorsza droga do tego doniosłego celu" "73. Podobne zmiany personalne dokonano na niższych szczeblach hierarchii cerkiewnej. W konsystorzach diecezjalnych preferowano ludzi bezwolnych, głównie narodowości rosyjskiej, bardziej uległych wobec polityki państwa. Usunięto z konsystorzy wileńskiego i grodzieńskiego osoby o wyraźnie ukształtowanej świadomości białoruskiej ${ }^{74}$.

Kościót w II Rzeczypospolitej, pod red. Z. Zielińskiego i St. Wilka, Lublin 1981, s. 165.

72 . M. Papierzyńska-Turek, Między tradycja..., s. 115-116; A. B. Kapташев, Жизненный путь Митрополита-Экзарха Владимира. К пятидесятилетию архиерейской хиротонии, Париж 1957; Митрополит Владимир - святитель и молитвенник (1873-1959), с. 35-39. Za wierność Rosyjskiemu Kościołowi Prawosławnemu patriarcha Tichon 30 listopada 1923 r. nadał mu godność arcybiskupa. Abp Włodzimierz wyjechał do Paryża, gdzie 10 czerwca 1930 r. został podniesiony do godności metropolity. Jemu to powierzono zarządzanie parafiami rosyjskimi znajdującymi na terenie Europy Zachodniej. Metropolita Włodzimierz 9 marca 1946 r. wyjechał do patriarchatu konstantynopolitańskiego, gdzie przebywał aż do śmierci w 1959 r. В. Цыпин Истории Русской Церкви 1917-1997, Москва 1997, s. 731.

73 K. Srokowski, Sprawa narodowościowa..., s. 48.

74 М. Давидюк, Справа беларусізаиі Правослаунай ичарквы у святле палітыкі дзяржаўных улад 1919-1939, „Беларускі каляндар”, Беласток 1990, с. 72-73. 
Wymienione fakty wskazują na charakterystyczna politykę personalną $\mathrm{w}$ obsadzie najwyższych stanowisk cerkiewnych. Ordynariuszami diecezji prawosławnych w pierwszych latach II Rzeczypospolitej byli biskupi wyświęceni przed 1918 r. Większość z nich (metropolita Jerzy Jaroszewski, biskup wileński Eleuteriusz Bogojawleński, arcybiskup wileński Teodozjusz Fiedosiejew, arcybiskup grodzieński Aleksy Gromadzki i arcybiskup poleski Aleksander Inoziemcow, biskup białostocki Włodzimierz Tichonicki, biskup krzemieniecki, późniejszy metropolita Dionizy Waledyński, biskup ostrogski Szymon Iwanowski, biskup lubelski Sawa Sowietow) była narodowości rosyjskiej. Białorusinem z pochodzenia był władyka polesko-piński Pantelejmon Rożnowski zaś Ukraińcami byli władyka krzemieniecki Aleksy Gromadzki, łucki - Polikarp Sikorski i grodzieński - Antoni Marcenko. Za Polaków uważali się dwaj wyświęceni w przed II wojna światową biskupi Tymoteusz (Jerzy) Szretter i Mateusz (Konstanty) Siemaszko.

Większość biskupów, która objęła katedry prawosławne w Polsce, pochodziła ze środowisk emigracyjnych. Biskupi ci wyjechali w latach 1918-1919 z Rosji i po pobycie najczęściej w Jugosławii lub Włoszech przyjechali do Polski na zaproszenie władz państwowych i cerkiewnych. Z Jugosławii do Polski przybyli biskup grodzieński Aleksy (1921), biskup poleski Aleksander (1921), biskup ostrogski Szymon (1924), biskup lubelski Sawa (1926). Z Włoch do Polski przyjechał abp Jerzy Jaroszewski. Władyka krzemieniecki Dionizy Waledyński i łucki Polikarp Sikorski w latach 1917-1918 byli uczestnikami Wszechukraińskiego Soboru Cerkiewnego. Ten ostatni wraz z biskupem wołyńskim Aleksym przybył w granice państwa polskiego w 1922 r. Biskupi, głownie narodowości rosyjskiej, zdający sobie sprawę z sytuacji Cerkwi prawosławnej w Rosji Radzieckiej wiązali swoją przyszłość z państwem polskim, podkreślając swój lojalny stosunek wobec rządu II Rzeczypospolitej.

Pierwsze pełne dane statystyczne dotyczące Kościoła prawosławnego w II Rzeczypospolitej pochodzą dopiero z 1922 r., kiedy to ostatecznie ukształtowały się granice państwa polskiego. Kościół prawosławny składał się z pięciu diecezji. Największą pod względem obszaru była diecezja warszawska, która zajmowała powierzchnię 231585 $\mathrm{km}^{2}$. Diecezja metropolitalna obejmowała województwo lubelskie, łódzkie, warszawskie, kieleckie, lwowskie, pomorskie, poznańskie, tarnopolskie, stanisławowskie i śląskie oraz miasto Warszawę. Władyctwo warszawskie dzieliło się na 7 dekanatów, 53 parafii etatowych i 11 filii. Diecezję obsługiwało 73 duchownych i 69 służby cerkiewnej (diakonów i psalmistów). Według danych władz cerkiewnych na terenie diecezji zamieszkiwało 215021 wyznawców prawosławia. $\mathrm{Na}$ jedną cerkiew parafialną przypadało 3360 wiernych, a na duchownego etatowego $-2945$.

Drugą pod względem wielkości powierzchni była diecezja pińsko-poleska - $42280 \mathrm{~km}^{2}$. Granice diecezji pokrywały się głównie z granicami województwa poleskiego. W skład biskupstwa poleskiego wchodziło 26 de- kanatów, 228 parafii etatowych i 91 filialnych. Diecezję obsługiwało 330 duchownych i 324 służby cerkiewnej. Władyctwo polesko-pińskie liczyło 917862 wiernych. Statystycznie na jedną parafię przypadało 2877 wiernych, a na duchownego - 2 781. Diecezja grodzieńsko-nowogródzka obejmowała obszar województwa białostockiego oraz czterech powiatów województwa nowogródzkiego: baranowickiego, nieświeskiego, nowogródzkiego i słonimskiego. W sumie granice władyctwa zajmowały 32450 $\mathrm{km}^{2}$. Biskupstwa grodzieńskie było podzielone na 17 dekanatów, 135 parafii etatowych i 45 filialnych. Diecezję obsługiwało 193 duchownych i 186 służby cerkiewnej. Władyctwo grodzieńskie liczyło 624302 wiernych. Statystycznie na jedną parafię przypadało 3468 wiernych, a na duchownego - 3235.

Niewiele mniejszą pod względem obszaru była diecezja wołyńska zajmująca $30274 \mathrm{~km}^{2}$ i pokrywająca się z obszarem województwa wołyńskiego. Biskupstwo podzielone było na 55 dekanaty, które obejmowały 426 parafii etatowych i 137 filialnych. Eparchię obsługiwało 569 duchownych i 568 służby cerkiewnej. Władyctwo wołyńskie liczyło 1192390 wiernych. Statystycznie na jedną parafię przypadało 2118 wiernych, a na duchownego 2096.

Najmniejszą jednostkę diecezjalną stanowiła diecezja wileńska, która zajmowała obszar 29109 km². Eparchia wileńsko-lidzka rozciągała się na tereny województwa wileńskiego i trzech powiatów województwa nowogródzkiego: lidzki, stołpecki i wołożyński. Diecezja dzieliła się na 12 dekanaty oraz 97 parafii etatowych i 22 filialnych. Eparchię obsługiwało 125 duchownych i 121 służby cerkiewnej. Władyctwo wileńskie liczyło 306152 wiernych. Statystycznie na jedną parafię przypadało 2572 wiernych, a na duchownego - 2449.

W sumie po pierwszych latach rewindykacyjnych Kościół prawosławny w 1922 r. liczył 122 dekanatów, które obejmowały 982 parafie etatowe i 312 filialnych. Parafie były obsługiwane przez 1340 duchownych i 1319 osób służby cerkiewnej. Liczba wiernych była szacowana na 3405963 osób. Na jedną parafię średnio przypadało 2632 wiernych, a na duchownego - $2542^{75}$. Powyższe dane uwzględniają jedynie te jednostki parafialne, które były uznawane przez państwo. W rzeczywistości liczba parafii i świątyń prawosławnych według źródeł cerkiewnych była znacznie większa. Przykładem mogą być dane odnoszące się do diecezji wileńskiej. Według konsystorza wileńskiego w 1922 r. w 15 dekanatach eparchii znajdowało się 217

\footnotetext{
75 Lietuvos Valstybės Istorijos Arhivas w Wilnie, f. 605, op. 10, nr 32, k. 1-5; AAN, MWRiOP, nr 1011, k. 51. Nieco inne dane podaje „Kalendarz Prawosławny" wydawany przez Warszawską Metropolię Prawosławną na rok 1923. Według tego źródła w końcu 1922 r. biskupstwo warszawsko-chełmskie liczyło 7 dekanatów i 55 parafii. Diecezja wileńsko-lidzka posiadała 12 dekanatów i 120 parafii. Eparchia wołyńska składała się z 61 dekanatów z 760 parafiami, a grodzieńsko-nowogródzka z 8 dekanatów i 100 parafii. Biskupstwo polesko-pińskie posiadało 21 dekanatów i 211 parafii. „Православный календарь” на 1923 год, Варшава 1923, с. 55-60; A. Mironowicz, Kościól prawosławny na ziemiach polskich w XIX i XX wieku, s. 99-100; tenże, Kościół prawosławny w Polsce, s. 530-532.
} 
parafii $^{76}$. Jeżeli nawet od tej liczby odejmiemy trzy dekanaty, które weszły w skład Republiki Litewskiej, to i tak liczba parafii będzie większa od danych ogłoszonych przez czynniki rządowe. Różnica ta bierze się z faktu uznania przez konsystorze diecezjalne również tych parafii świeckich i zakonnych, na których funkcjonowanie nie wyraziły zgody władze państwowe. Przykładem może być parafia zakonna w Berezweczu, która faktycznie została zlikwidowana, a mniszki tego monasteru zostały przeniesione do klasztoru Św. Trójcy w Wilnie.

\section{Status kanoniczny i problem autokefalii}

W okresie, kiedy rozpoczęto prace nad ustanowieniem autokefalii nadal prowadzona była akcja rewindykacyjna wobec prawosławnych obiektów sakralnych i majątków cerkiewnych $^{77}$. Działania władz państwowych i Kościoła łacińskiego doprowadziły do licznych protestów skierowanych do władz państwowych i cerkiewnych, instytucji międzynarodowych i zwierzchników Kościołów. 19 czerwca 1922 r. ponad stu mieszkańców powiatów grodzieńskiego, białostockiego, wołkowyskiego, bielskiego, sokólskiego, brzeskiego, słonimskiego, baranowickiego, nieświeskiego, nowogródzkiego, dziśnieńskiego i pińskiego wystosowało do nuncjusza apostolskiego Laurentiusa Lauri w Polsce list w sprawie prześladowania ludności prawosławnej. Z uwagi na użyte w nim interesujące argumenty warto zacytować obszerne fragmenty listu. ,W imieniu prawosławnych Białorusinów Grodzieńszczyzny pozostającej pod okupacja polską prosimy o przekazanie Ojcu Świętemu o terrorze, gwałtach i poniżeniach, jakie się dokonują nad Białorusinami i Cerkwią prawosławną. Dwóch biskupów Pantelejmona - nowogródzkiego i Sergiusza - bielskiego aresztowano i wyrzucono, a Włodzimierz, biskup grodzieński, pozostaje pod strażą żandarmerii. Cerkwie i monastery są zamykane, duchowni aresztowani i osadzeni w więzieniach lub wysyłani za granicę. Dobra cerkiewne niszczeją. Szkoły białoruskie zamknięte, a duchownym zabrania się katechizacji dzieci. Wszystko to czyni polskie katolickie duchowieństwo, razem z rządem polskim. Z tego powodu powstaje konflikt między prawosławnymi a katolikami Białorusinami, jaki wcześniej nie występował. Polsko-katolicki terror i gwałt szkodzi nie tylko dla naszego narodowego odrodzenia, ale również osłabia walkę z bolszewizmem, na którą Polska otrzymała mandat od Ententy, a teraz sama niszczy Cerkiew nie patrząc, że naród białoruski ze względu na swój charakter nie sprzyja bolszewikom.

\footnotetext{
76 Lietuvos Valstybès Istorijos Arhivas w Wilnie, f. 605, op. 10, nr 32, k. 1-5.

77 A. Mironowicz, Rewindykacja prawosławnych obiektów sakralnych w II Rzeczypospolitej, „Białoruskie Zeszyty Historyczne”, Białystok 2004, nr 21, s. 83-103; tenże, Rewindykacja i niszczenie prawosławnych obiektów sakralnych na terenie II Rzeczypospolitej, „Е $\Lambda \Pi І \Sigma$. Czasopismo Katedry Teologii Prawosławnej Uniwersytetu w Białymstoku”, Bia-

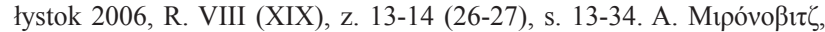

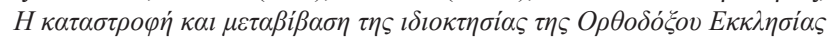

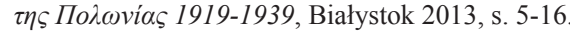

Wysyłamy celem dokumentacji książkę Uspaminy ab polskoj akupacji Grodzieńszczyny gdzie podane są konkretne fakty terroru" "78. W podobnym tonie sformułowany został memoriał rządu Białoruskiej Republiki Narodowej skierowany do patriarchy Tichona jeszcze 27 stycznia $1921 \mathrm{r}^{79}$ Ostry protest wystosowali także przedstawiciele Rosyjskiego Emigracyjnego Kościoła Prawosławnego w Sremskich Karłowcach, na czele z metropolitą Antoniuszem Chrapowickim $^{80}$.

Napięta sytuacja w Kościele prawosławnym w Polsce na tle walki o autokefalię doprowadziła do tragedii. 8 lutego 1923 r. były rektor seminarium duchownego w Chełmie archimandryta Smaragd dokonał zabójstwa metropolity Jerzego ${ }^{81}$. Dwa dni później abp Dionizy, jako senior biskupów, objął obowiązki metropolity ${ }^{82}$. Członkiem Synodu został biskup grodzieński Aleksy. 25 lutego 1923 r. na biskupa lubelskiego wyświęcony został archimandryta Antoni (Marcenko), który uzupełnił Sobór Biskupów. W takim składzie sobór mógł przystąpić do wyboru nowego metropolity ${ }^{83}$. Sobór Biskupów 27 lutego 1923 r. postanowił powołać na stanowisko metropolity arcybiskupa wołyńskiego Dionizego z tytułem metropolity Warszawskiego i Wołyńskiego i całego Prawosławnego Kościoła w Polsce ze wszystkimi zewnętrznymi odznaczeniami danymi przez patriarchę Tichona metropolicie Jerzemu oraz nadał mu godność archimandryty Ławry Poczajowskiej ${ }^{84}$. O uchwale soboru powiadomiono rząd polski, aby ten wyraził swoją aprobatę. $\mathrm{Z}$ powodu braku kontaktu z patriarchą moskiewskim zwrócono się o zatwierdzenie wyboru metropolity warszawskiego do patriarchy ekumenicznego ${ }^{85}$. Patriarcha Melecjusz IV telegraficznie, 13 marca 1923 r., przychylił się do prośby i udzielił władyce Dionizemu swego błogosławieństwa. Kościół prawosławny w Rzeczypospolitej stanął na stanowisku, że aktem tym został on uznany za autonomiczny, poddany jurysdykcji patriarchatu konstantynopolitańskiego. Na błogosławieństwo metropolita Dionizy odpowiedział patriarsze listem z 1 kwietnia 1923 r., w którym pisał.: „Całuję Twą pra-

\footnotetext{
78 НГАБ, ф. 325, оп. 1, нр 128, к. 77-78; А. Mironowicz, Kościół prawostawny $w$ Polsce, s. 533.

79 НГАБ, ф. 325, оп. 1, нр 128, к. 33-36.

80 K. Krasowski, Zwiazki wyznaniowe..., s. 123; J. S. Langrod, O autokefalii..., s. 80-81; О. Ф. Купранець, Православна иерква в міжвоєнній Польщіi, 1918-1939, с. 13-14; М. Papierzyńska-Turek, Kościót prawostawny..., s. 58 .

81 Archimandryta Smaragd (Paweł Antonowicz Łatyszenko) wyróżniał się wysokim poziomem intelektualnym i władczym charakterem, nie łatwym w stosunkach z władzami duchownymi. Archimandryta miał być wyświęcony na biskupa słuckiego, sufragana diecezji mińskiej. Za naruszenie dyscypliny kościelnej został zasuspendowany przez metropolitę Jerzego. Smaragd przeciwstawiał się zmianom w Kościele prawosławnym w Polsce. Za swój czyn został skazany na 12 lat więzienia. AAN, MWRiOP, nr 1233, k. 74; M. Papierzyńska-Turek, Kościót prawosławny..., s. 22; S. Kiryłowicz, Z dziejów prawosławia..., s. 49; A. Borkowski, Między Konstantynopolem a Moskwa, s. 43-46.

82 M. Zyzykin, Autokefalia..., s. 62.

83 Алексий (Громадский) архиепископ, $K$ истории Православной Церкви в Польше..., с. 44; G. J. Pelica, Kościól prawosławny w województwie lubelskim (1918-1939), s. 101.

84 А. Свитич, Православная Церковь в Польше и ее автокефалия, c. 126 .

85 Tamże, s. 45.
} 
wicę arcypasterską, od której dziś przyjmuję metropolię prawosławną w Polsce" ${ }^{" 86} .8$ kwietnia 1923 r. Synod Biskupów postanowił „Arcybiskupowi Dionizemu przyznać tytuł Metropolity Warszawskiego i Wołyńskiego i całego Prawosławnego Kościoła w Polsce, a także godność Archimandryty Poczajowskiej Ławry i nałożyć na niego biały kłobuk z brylantowym krzyżem, a także nakładać podczas nabożeństwa mitrę z krzyżem i wprowadzić podczas jego nabożeństwa niesienie przed nim św. Krzyża”. Oprócz tego ustalono, że podczas nabożeństwa celebrowanego przez metropolitę, będzie się wspominać patriarchę konstantynopolitańskiego Melecjusza IV, bezpośrednio po patriarsze moskiewskim Tichonie $^{87} .29$ kwietnia $1923 \mathrm{r}$. w cerkwi monasteru Objawienia Pańskiego w Krzemieńcu metropolita Dionizy został intronizowany ${ }^{88} .6$ kwietnia w tejże samej świątyni na biskupa krzemienieckiego został wyświęcony przełożony monasteru Objawienia Pańskiego archimandryta Szymon (Iwanowski). A 2 maja 1923 r. Synod na ordynariusza diecezji wileńsko-lidzkiej powołał byłego arcybiskupa odeskiego i chersońskiego Teodozjusza (Mikołaja Fiedosiejewa) ${ }^{89}$.

W ten sposób sytuacja kanoniczna Kościoła prawosławnego w Polsce stała się jeszcze bardziej złożona. Kościół prawosławny, przyjmując błogosławieństwo od patriarchy konstantynopolitańskiego, administracyjnie podporządkował się patriarsze ekumenicznemu. Chociaż formalnie metropolita warszawski uznawał dwóch zwierzchników zewnętrznych, ale jedynie kontakty z patriarchą ekumenicznym mogły przyspieszyć uzyskanie autokefalii. Starania te, oprócz władz kościelnych, podjęło poselstwo polskie ${ }^{90}$. Sytuacja prawna Kościoła prawosławnego uległa jeszcze większemu skomplikowaniu, kiedy w lipcu 1923 r. patriarcha Tichon został wypuszczony

\footnotetext{
86 M. Papierzyńska-Turek, Między tradycja..., s. 121; M. Zyzykin, Autokefalia..., s. 62-63; K. Krasowski, Zwiazki wyznaniowe..., s. 124-125. Pogląd o Konstantynopolu jako o „kościele macierzystym” pochodziły zapewne z inspiracji rządu, który w swoich wywodach kładł nacisk na związki z Konstantynopolem pochodzące z końca I Rzeczypospolitej. Podobny argument został zawarty w thomosie udzielonym Kościołowi prawosławnemu przez patriarchę konstantynopolitańskiego. A. Borkowski, Między Konstantynopolem a Moskwa, s. 65-75.

87 Алексий (Громадский) архиепископ, К истории Православной Церкви в Польше..., с. 46; М. Papierzyńska-Turek, Między tradycją..., s. 122 , przyp. 61 .

88 Алексий (Громадский) архиепископ, К истории Православной Церкви в Польше.., с. 46-47. Biografia metropolity Dionizego, s. 2243. T. Wyszomirski, Kościót prawosławny w Polsce w latach 1918-1939, „Novum” 1980, nr 3, s. 105, przyp. 1. Metropolita Dionizy (Konstanty N. Waledyński) urodził się w 1876 r. w Muromie. Studia teologiczne odbył w Kazańskiej Duchownej Akademii. Po złożeniu w 1897 r. ślubów zakonnych pełnił szereg funkcji. Był między innymi rektorem seminarium w Chełmie. W 1913 r. został uchwałą Synodu w Petersburgu mianowany biskupem krzemienieckim. W latach 1919-1922 był biskupem wołyńskim i archimandryta Ławry Poczajowskiej, a od 1922 r. arcybiskupem. Zorganizował i został kierownikiem Studium Teologii Prawosławnej Uniwersytetu Warszawskiego. Por. S. Dudra, Metropolita Dionizy (Waledyński) 1876-1960), Warszawa 2010.

${ }^{89}$ A. Mironowicz, Kościót prawostawny na ziemiach polskich w XIX i XX wieku, s. 102-103.

90 J. S. Langrod, O Autokefalii..., s. 81. Pierwszy swą zgodę na autokefalię Kościoła prawosławnego w Polsce wyraził Synod Rumuńskiego Kościoła Prawosławnego.
}

na wolność ${ }^{11}$. Patriarcha poinformował zwierzchników diecezji patriarchatu moskiewskiego, w tym metropolitę warszawskiego, o ponownym objęciu przez siebie urzędowania $^{92}$. W tej sytuacji 18 listopada 1923 r. metropolita Dionizy wystosował do patriarchy Tichona pismo informujące o śmierci metropolity Jerzego i o swoim wyborze na stanowisko metropolity zatwierdzonym błogosławieństwem patriarchy Melecjusza IV. W piśmie metropolita Dionizy prosił patriarchę o przyznanie autokefalii Cerkwi prawosławnej w Rzeczypospolitej. Pismo to było pierwszą próbą legalizacji autokefalii przez Kościół macierzysty ${ }^{93}$. $\mathrm{W}$ odpowiedzi na list metropolity Dionizego patriarcha Tichon 23 maja 1924 r. odmówił zgody na autokefalię. Swoją decyzję uzasadnił prawem kościelnym, zgodnie z którym zgodę na autokefalię mógł wyrazić jedynie sobór biskupów, a nie patriarcha. Hierarcha stwierdził, że patriarcha konstantynopolitański nie posiada jurysdykcji w obrębie patriarchatu moskiewskiego. W zakończeniu patriarcha Tichon dodał, że wobec niedostatecznych i sprzecznych informacji, nie może wyrazić swojej zgody dopóki wszystkie okoliczności i argumenty kanoniczne nie będą przedstawione Soborowi Biskupów Rosyjskiego Kościoła Prawosławnego ${ }^{94}$.

Po otrzymaniu odpowiedzi patriarchy Sobór Biskupów postanowił szczegółowo wyjaśnić zwierzchnikowi Rosyjskiego Kościoła Prawosławnego zaistniałą sytuację i przekonać hierarchę do zmiany swego stanowiska. Sobór Biskupów 16 sierpnia 1924 r. wystosował obszerne pismo, w którym przedstawił losy Kościoła prawosławnego w Polsce od 1918 r. do chwili uwolnienia patriarchy Tichona i zapoznał z motywami dotychczasowych posunięć w kierunku usamodzielnienia się Kościoła ${ }^{95}$. W piśmie do patriarchy Synod poinformował o swym składzie i o potrzebie szybkiego powołania biskupów wikarych w Krzemieńcu, Łucku i Włodzimierzu Wołyńskim. Potwierdzono, że w skład Synodu Biskupów wchodzą metropolita warszawski Dionizy, arcybiskup wileński Teodozjusz, biskup grodzieński Aleksy, biskup poleski Aleksander i biskup lubelski Antoni.

Korespondencja $\mathrm{z}$ uwolnionym $\mathrm{z}$ więzienia patriarchą Tichonem uzmysłowiła, że nie było nadziei na ewolucję poglądów zwierzchnika Rosyjskiego Kościoła Prawosławnego. Równolegle rząd polski domagał się, ażeby

\footnotetext{
91 J. S. Langrod, O Autokefalii..., s. 54.

92 M. Zyzykin, Autokefalia..., s. 63.

93 S. Żeleźniakowicz, Z historii..., „WPAKP” 1983, nr 1/2, s. 42. Rząd widząc niepewność sytuacji na początku 1924 r. zażądał od biskupów prawosławnych i duchowieństwa podpisania deklaracji o „uznaniu bez zastrzeżeń autokefalicznego ustroju Kościoła prawosławnego w Polsce z zobowiązaniem współpracować w pełnym jego urzeczywistnianiu oraz uznaniu go przez wszystkich prawosławnych". 12 kwietnia 1924 r. biskupi na soborze biskupów podpisali deklarację, a pismem z 14 kwietnia 1924 r. metropolita Dionizy zezwolił na egzekwowanie przez wojewodów podobnych deklaracji od duchownych prawosławnych.

94 M. Zyzykin, Autokefalia..., s. 100; K. Krasowski, Związki wyznaniowe..., s. 125

95 M. Papierzyńska-Turek, Między tradycją..., s. 120. Pełny tekst pisma do patriarchy Tichona z dnia 16 sierpnia 1924 r. w: Алексий (Громадский) архиепископ, К истории Православной Церкви в Польше..., c. 146-163. Aneks 6.
} 
metropolita Dionizy utrzymywał stałą korespondencję z następcą patriarchy Melecjusza IV, Grzegorzem VII, który był zainteresowany sytuacją Kościoła prawosławnego w Polsce ${ }^{96}$. Pertraktacje władz rządowych doprowadziły do ustalenia wysokości daru pieniężnego w wysokości 12000 funtów szterlingów, który 24 listopada $1924 \mathrm{r}$. został wysłany do Konstantynopola ${ }^{97}$. Parę dni wcześniej, 11 listopada 1924 r. Synod Patriarszy w Konstantynopolu podjął uchwałę o udzieleniu błogosławieństwa nowo powstałej autokefalii Kościoła w Polsce, a 13 listopada 1924 r. patriarcha Grzegorz VII podpisał odpowiedni thomos ${ }^{98}$. 15 stycznia 1925 r. następca Grzegorza VII, Konstanty VI ogłosił dwa orędzia: jedno skierowane do metropolity Dionizego z oficjalnym zawiadomieniem go o treści thomosu z 13 listopada 1924 r., drugie skierowane do wszystkich autokefalicznych Kościołów prawosławnych świata „o uznaniu Kościoła prawosławnego w Polsce za Kościół autokefaliczny", którego tekst był zbliżony do treści thomosu $^{99}$. Wcześniej, 27 grudnia 1924 r. metropolita Dionizy (Waledyński) został przez prezydenta Rzeczypospolitej nagrodzony wielką wstęgą orderu Odrodzenia Polski, ,za zasługi położone przy organizowaniu Kościoła prawosławnego w Polsce"100.

Thomos patriarszy uznawał autonomiczną organizację Kościoła prawosławnego w Polsce nadaną 17 września 1921 r. przez patriarchę moskiewskiego i potwierdzał niezależność organizacyjną. Podane zostały przy tym obiektywne przesłanki, które nakazywały udzielić autokefalii. W thomosie wymieniono wytrwałość w wierze, troskę o sprawy kościelne oraz okoliczności polityczne. Patriarcha uzasadnił swoje prerogatywy do polskiej organizacji cerkiewnej kanonicznym obowiązkiem Kościoła konstantynopolitańskiego do troszczenia się o znajdujące się w potrzebie Kościoły prawosławne, faktem złamania przepisów kanonicznych przy przyłączaniu metropolii kijowskiej oraz metropolii litewskiej do patriarchatu moskiewskiego w 1685 r. i pozbawienia autonomii kościelnej metropolii kijowskiej w składzie patriarchatu. W thomosie patriarszym jednoznacznie stwierdzono, że Kościołem Matką metropolii kijowskiej był patriarchat konstantynopolitański, tak jak dla wszystkich kościołów w krajach słowiańskich. Z uwagi na fakt, że większość ziem metropolii kijowskiej znalazło się w granicach II Rzeczypospolitej, Kościół prawosławny na jej terytorium pozostał w kanonicznej jedności z patriarchatem ekumenicznym. W thomosie pominięto, że Rosyjski Kościół Prawosławny był przez długi czas macierzystą jednostką wobec Kościoła prawosławnego w Polsce. Na końcu zo-

\footnotetext{
96 А. Свитич, Православная Церковь в Польше и ее автокефалия, c. 131. M. Papierzyńska-Turek, Między tradycją..., s. 122.

97 S. Żeleźniakowicz, Z historii..., „WPAKP” 1983, nr 1/2, s. 42-43.

98 A. Friszke, Kościoty wschodnie..., s. 88; А. Свитич, Православная Церковь в Польше и ее автокефалия, с. 132; J. S. Langrod, O autokefalii..., s. 90-92; Алексий (Громадский) архиепископ, К истории Православной Церкви в Польше.., с. 139-142; M. Zyzykin, Autokefalia..., s. 74-89.

99 J. S. Langrod. O autokefalii..., s. 94-96; Алексий (Громадский) архиепископ, К истории Православной Церкви в Польше..., с. 142-144.

100 J. S. Langrod, O autokefalii..., s. 93, przypis 2.
}

bowiązano metropolitę warszawskiego do otrzymywania św. mira z Konstantynopola, powiadamiania patriarchy ekumenicznego o intronizacjach na katedrę metropolity oraz wspominania go i pozostałe głowy autokefalicznych Kościołów podczas nabożeństw ${ }^{101}$.

W odpowiedzi na thomos patriarszy 12 lutego $1925 \mathrm{r}$. Synod Kościoła prawosławnego w Polsce podjął uchwałę, w której złożył podziękowania patriarsze ekumenicznemu i Synodowi ,za rodzicielską troskę w budowie Prawosławnego Kościoła w Polsce" i zwrócił się do niego z prośbą o przysłanie do Warszawy przedstawiciela, który uroczyście przekazałby Kościołowi prawosławnemu w Polsce błogosławieństwa Kościoła Matki na autokefaliczną organizację oraz wręczył thomos. Pod decyzją Synodu podpisali się metropolita warszawski Dionizy, arcybiskup wileński i lidzki Teodozjusz, biskup piński i poleski Aleksander, biskup grodzieński i nowogródzki Aleksy, biskup lubelski Antoni i biskup krzemieniecki Szymon. Władze kościelne zwlekały z opublikowaniem informacji o uzyskaniu autokefalii. Obawiano się reakcji patriarchy Tichona, z którym episkopat polski musiał się liczyć. Biskupi starali się wpłynąć na rząd, ażeby przy okazji ogłoszenia autokefalii zatwierdzić statut wewnętrzny Kościoła i przyspieszyć ustawowe uregulowanie jego sytuacji prawnej ${ }^{102}$.

W kwietniu 1925 r. w klasztorze dońskim pod Moskwą zmarł patriarcha Tichon ${ }^{103} .22$ kwietnia 1925 r. metropolita Dionizy powiadomił prezesa Rady Ministrów o posiedzeniu Synodu Kościoła prawosławnego, na którym wysłuchano pismo Świętego Synodu Ekumenicznego z 13 listopada 1924 r. w sprawie uznania Kościoła prawosławnego w Polsce za Kościół autokefaliczny, patriarchalny i synodalny, thomos patriarchatu ekumenicznego z 13 listopada 1924 r. oraz pismo patriarchy konstantynopolitańskiego Konstantyna VI na imię metropolity Dionizego z 15 stycznia 1925 r. Metropolita prosił rząd, aby podjęto działania w celu nadania decyzjom zawartym w powyższych pismach charakteru prawnego ${ }^{104}$.

Oficjalne ogłoszenie autokefalii nie nastąpiło szybko, albowiem najpierw zmarł patriarcha Grzegorz VII, a pod koniec stycznia 1925 r. patriarcha Konstantyn VI został przez władze tureckie wydalony z Konstantynopola i aż do lipca tegoż roku tron patriarszy był nieobsadzony. Dopiero w lipcu 1925 r. na tron patriarszy wstąpił Bazyli III, który w piśmie z 20 sierpnia zawiadamiał metropolitę Dionizego o planowanym przybyciu w połowie września delegacji patriarchatu i oficjalnym wręczeniu thomosu ${ }^{105}$. Metropolita Dionizy pragnął ten moment wykorzystać do unormowania stanu prawnego Kościoła prawosławnego w Polsce. Widząc opieszałość ze strony rządu, metropolita postano-

101 А. Свитич, Православная Церковь в Польше и ее автокефалия, c. 133-134.

102 J. S. Langrod, O autokefalii..., s. 99-101; M. Papierzyńska-Turek, Między tradycją..., s. 124.

103 J. S. Langrod, $O$ autokefalii..., s. 54, przypis 4.

104 S. Żeleźniakowicz, Z historii..., „WPAKP” 1983, nr 1/2, s. 51-52.

105 А. Свитич, Православная Церковь в Польше и ее автокефалия, c. 135-136; A. Borkowski, Między Konstantynopolem a Moskwa, s. 125134. 
wił, na znak protestu, nie uczestniczyć w uroczystościach. Tuż przed wyznaczonym terminem proklamacji autokefalii, 9 września 1925 r., metropolita wyjechał do Karlsbadu „na leczenie", informując o tym ministra WRiOP ${ }^{106}$.

Działania metropolity miały na celu dokonanie zmian w Tymczasowych przepisach, które nie były zgodne z konstytucją marcową i nie normowały w sposób właściwy spraw Kościoła prawosławnego w Polsce. Metropolita domagał się uregulowania położenia prawnego Kościoła w sposób ustawowy. Przygotowanie odpowiedniego projektu napotykało na wiele przeszkód. Projekt ustawy o stosunku państwa do Kościoła prawosławnego został przygotowany jeszcze we wrześniu $1923 \mathrm{r}$. i był przesłany do konsultacji metropolicie Dionizemu. W projekcie tym władze państwowe stały na stanowisku, że to rządowi przysługuje prawo rozporządzania majątkiem kościelnym. Z kolei metropolita Dionizy uważał, że Kościół prawosławny jest właścicielem posiadanych nieruchomości ${ }^{107}$. Konsultacje nad pierwszym projektem ustawy rozpoczęto w kwietniu 1924 r., ale wkrótce ją przerwano. Premier Władysław Grabski był zdania, że szczegółowe opracowanie ustawy należy odroczyć do czasu zawarcia konkordatu ze Stolicą Apostolską, aby dokument ten nie komplikował rokowań z Watykanem ${ }^{108}$. Po podpisaniu konkordatu, 28 marca 1925 r. minister WRiOP na posiedzeniu Rady Ministrów poinformował, że w najbliższych dniach zostaną opracowane zasadnicze tezy projektu ustawy o położeniu prawnym Kościoła prawosławnego ${ }^{109} .13$ kwietnia władze kościelne, mając na uwadze prowadzone przez MWRiOP prace nad projektem ustawy, opracowały i przedłożyły kodeks przepisów o wewnętrznym ustroju kościelnym pod nazwą „Statut zasadniczy wewnętrznego kanonicznego ustroju Polskiego Autokefalicznego Św. Kościoła Prawosławnego". Synod biskupów przyjął go na posiedzeniach 13 kwietnia i 5 czerwca 1925 r., a publicznie ogłosił 1 lipca 1926 r. ${ }^{110}$

Dokument ten zawierał 44 artykuły. Artykuł pierwszy głosił, że Kościół prawosławny w Polsce posiada ustrój autokefaliczny, a drugi, że „korzysta w życiu wewnętrznym z pełnej wolności rządzenia się ustawami z zachowaniem przepisów obowiązującego prawa państwowego". Statut omawiał ustrój Kościoła i wymieniał jego instytucje. Statut przewidywał utworzenia Rady Metropolitalnej, składającej się z duchownych i laików, która zapewniałaby metropolicie szersze oparcie społeczne w kołach świeckich oraz wzmocniła jego pozycję w stosunkach z rządem. Statut był sformułowany w sposób bardzo ogólny i nie ujmował wielu spraw szczegółowych, np. nauczania religii. Rząd nie podjął dyskusji nad przedłożonym statutem, co w konsekwencji doprowadziło do wstrzymania prac nad

\footnotetext{
$106 \quad$ S. Żeleźniakowicz, $Z$ historii..., „WPAKP” 1983, nr 1/2, s. 52; A. Mironowicz, Kościót prawostawny na ziemiach polskich w XIX i XX wieku, s. 106-107; tenże, Kościót prawostawny w Polsce, s. 537-538.

107 K. Krasowski, Zwiazki wyznaniowe..., s. 160.

108 M. Papierzyńska-Turek, Między tradycja..., s. 157.

109 K. Krasowski, Zwiazki wyznaniowe..., s. 166.

110 J. S. Langrod, O Autokefalii..., s. 108-111.
}

ustawą $^{111}$. W tej sytuacji zrozumiała była postawa metropolity odmawiającego udziału w akcie ogłoszenia autokefalii. Dopiero po uzyskaniu pisemnego zapewnienia szybkiego uregulowania ,stosunków prawnych tak wewnątrz Kościoła prawosławnego, jak i stosunku państwa do tego Kościoła" udzielonym przez ministra WRiOP prof. Stanisława Grabskiego, metropolita wrócił do Warszawy i wziął udział w uroczystościach ${ }^{112}$.

Uroczyste ogłoszenie autokefalii nastąpiło 17 września 1925 r. w katedrze metropolitalnej św. Marii Magdaleny w Warszawie przez wysłanników patriarchy ekumenicznego i członków Synodu konstantynopolitańskiego metropolitę chalcedońskiego Joachima, metropolitę sardyńskiego Hermanosa przy udziale delegata patriarchy rumuńskiego biskupa Nektariusza, przedstawicieli rządu polskiego z ministrem WRiOP Stanisławem Grabskim na czele i przedstawicieli wszystkich diecezji prawosławnych w Polsce. Thomos został wręczony metropolicie Dionizemu przez metropolitę Joachima ${ }^{113}$. Na pamiątkę tych wydarzeń rząd polski uhonorował orderami członków delegacji i osoby im towarzyszące, a metropolicie Dionize$\mathrm{mu}$ ofiarował dwie drogocenne złote panagije - symbole władzy biskupiej ${ }^{114}$. Pomimo zaproszenia na uroczystość ogłoszenia autokefalii nie przybyli przedstawiciele rosyjskich organizacji emigracyjnych ${ }^{115}$. Synod Kościoła prawosławnego w Polsce w 1925 r. wprowadził nazwę Polski Autokefaliczny Kościół Prawosławny.

Po oficjalnym ogłoszeniu autokefalii następnym krokiem było uzyskanie akceptacji ze strony innych Kościołów autokefalicznych i patriarchatu moskiewskiego. Stanowisko następców patriarchy Tichona w sprawie samodzielności Kościoła prawosławnego w Polsce było niezmienne. Protesty na ustanowienie autokefalii wnieśli najpierw namiestnik patriarchy metropolita Piotr, a po jego wygnaniu zastępca namiestnika patriarchy metropolita Sergiusz, który stwierdził, że patriarchat stoi na stanowisku autonomii udzielonej metropolii warszawskiej przez patriarchę Tichona, a kwestię autokefalii odsyła do decyzji najbliższego ogólnorosyjskiego Soboru ${ }^{116}$. W korespondencji z metropolitą Dionizym władyka Sergiusz starał się różnymi argumentami podważyć autentyczność autokefalii. Synod Kościoła prawosławnego w Polsce na posiedzeniu 15 kwietnia 1929 r. zapoznał się z korespondencją metropolity Sergiusza, a następnie przesłał ją patriarsze konstantynopolitańskiemu. Patriarcha konstantynopolitański stwierdził, że przyszłe „stosunki między prawosławnym Kościołem polskim a bratnim Kościołem rosyjskim winny pozostać $\mathrm{w}$ zgodzie $\mathrm{z}$ legalnie ustanowionym i kanonicznie istniejącym ustrojem autokefalicznym Kościoła

\footnotetext{
111 M. Papierzyńska-Turek, Między tradycja..., s. 158-159.

112 S. Żeleźniakowicz, Z historii..., „WPAKP” 1983, nr 3, s. 18.

113 K. Krasowski, Związki wyznaniowe..., s. 126; J. S. Langrod, O autokefalii..., s. 98-99. A. Łotocki, Autokefalia. Zasady Autokefalii, Warszawa 1932, s. 133-210; M. Zyzykin, Autokefalia..., s. 5-58.

114 А. Свитич, Православная Церковь в Польше и ее автокефалия, c. 137 .

115 M. Papierzyńska-Turek, Między tradycja..., s. 125, przyp.74.

116 J. S. Langrod, O autokefalii...,s. 97; M. Zyzykin, Autokefalia..., s. 94;

A. Borkowski, Między Konstantynopolem a Moskwą, s. 119-124.
} 
prawosławnego w Polsce"117. 27 października 1930 r. po otrzymaniu kolejnego pisma od metropolity Sergiusza, Synod postanowił zerwać kontakty z patriarchatem moskiewskim $^{118}$.

Reakcja Kościołów autokefalicznych na ogłoszenie niezależności Kościoła prawosławnego w Polsce była pozytywna. Żaden z nich nie zerwał kontaktów z Polskim Autokefalicznym Kościołem Prawosławnym. W takiej sytuacji metropolita Dionizy postanowił odbyć podróż do kilku Kościołów autokefalicznych. Podróż, która trwała od kwietnia 1927 r. do połowy maja 1927 r. miała ogromne znaczenie kościelno-religijne ${ }^{119}$. Wszystkie lokalne Kościoły prawosławne bezwarunkowo uznały potrzebę samodzielnego bytu prawosławnego Kościoła w Polsce na zasadach autokefalii, zwracając przy tym uwagę na to, że Rosyjski Kościół Prawosławny powinien zrozumieć sytuację ludności prawosławnej w Polsce i udzielić jej swojego błogosławieństwa. 7 kwietnia 1927 r. patriarcha konstantynopolitański potwierdził błogosławieństwo metropolicie warszawskiemu podkreślając, ,że Kościół prawosławny w Polsce podniesiony został do godności Kościołów autokefalicznych i nie tylko zorganizował i godnie uporządkował swe własne sprawy, lecz i zdążył już przynieść obfite owoce swej pracy w Panu"120. Wobec takiej postawy Kościołów autokefalicznych Rosyjski Zagraniczny Kościół Prawosławny na przełomie czerwca i lipca 1926 r. podjął rezolucję o uznaniu dotychczasowej działalności metropolity Dionizego za zgodną z kanonami Kościoła prawosławnego. We wrześniu 1927 r. Sobór Biskupów tego Kościoła w Sremskich Karłowicach podjął decyzję o nawiązaniu ,przyjacielskiego i modlitewnego związku" z hierarchią prawosławną w Polsce ${ }^{121}$. Mimo wysuwanego przez oponentów autokefalii zarzutu o jego niekanoniczności, autokefalia Kościoła prawosławnego w Polsce stała się faktem.

Akt z 17 listopada 1925 r. stwarzał nowy precedens w prawie kościelnym. Ogłoszenie autokefalii opierało się na uchwale poszczególnych Kościołów prawosławnych, przy braku zgody patriarchatu moskiewskiego. Posunięcia te były uzasadnione brakiem widoków na normalizację spraw wewnętrznych w Rosyjskim Kościele Prawosławnym i chaosem w nim panującym, wywołanym polityką wyznaniową bolszewików. Zakończone sukcesem zabiegi o autokefalię dały podstawy do wewnętrznej stabilizacji Kościoła prawosławnego w Polsce, ale nie wpłynęły, mimo obietnic przedstawicieli rządu, na przyspieszenie prac nad ustawami określającymi położenie prawne tego wyznania $^{122}$.

\footnotetext{
117 M. Zyzykin, Autokefalia..., s. 121.

118 M. Papierzyńska-Turek, Między tradycją..., s. 129-130.

119 Алексий (Громадский) архиепископ, К истории Православной Церкви в Польше..., с. 79-95; А. Borkowski, Między Konstantynopolem a Moskwa, s. 134-140.

120 M. Zyzykin, Autokefalia..., s. 89-90.

121 M. Papierzyńska-Turek, Między tradycją..., s. 128.

122 K. Krasowski, Zwiazki wyznaniowe..., s. 126-127; A. Mironowicz, Kościót prawosławny na ziemiach polskich w XIX i XX wieku, s. 108-110; tenże, Kościół prawosławny w Polsce, s. 540-541.
}

\section{Droga do uregulowania statusu prawnego i majątkowego}

Ustanowienie autokefalii nie oznaczało prawnego uregulowania statusu Kościoła prawosławnego w II Rzeczypospolitej. Synod PAKP podejmował próby znalezienia poparcia dla swych starań w klubach mniejszościowych, czym zaniepokoił kręgi rządowe ${ }^{123}$. Synod, który odbył się w dniach od 26 listopada do 3 grudnia 1925 r., zwrócił się do prezesa Rady Ministrów z memoriałem, w którym domagał się unormowania stosunku państwa do Kościoła prawosławnego. Po omówieniu sytuacji Kościoła prawosławnego w Polsce Synod uznał za niezbędne: przedłożenie parlamentowi projektu ustawy normalizującej sytuację prawną Kościoła; uregulowanie spraw budżetowych; przywrócenie Kościołowi jego własności; uregulowanie liczby i rozmieszczenia parafii prawosławnych; ograniczenie samowoli administracyjnej; zatwierdzenie statutu normatywnego bractw. Synod zwrócił też uwagę, że biskupi katoliccy ustanawiają nowe parafie rzymskokatolickie tam, gdzie władze świeckie zamknęły parafie prawosławne, a duchowni katoliccy zamknięte przez władze cerkwie wyświęcają na kościoły ${ }^{124}$. Synod zatwierdził zmiany w nazwach diecezji poleskiej i grodzieńskiej. Pierwsza uzyskała nazwę eparchii polesko-pińskiej, a druga grodzieńsko-nowogródzkiej. Na poparcie powyższego wystąpienia metropolity przedstawiciele księży i wiernych, zebrani w dniach 10-12 stycznia 1926 r. w Warszawie, uchwalili memorandum popierające memoriał metropolity i skierowali prośbę o przyspieszenie uregulowania sytuacji prawnej Kościoła prawosławnego poprzez zatwierdzenie statutu opracowanego przez Synod ${ }^{125}$. 9 marca 1926 r. władze kościelne przedłożyły własny projekt ustawy o położeniu prawnym Kościoła w państwie. MWRiOP projekt ustawy zbyło milczeniem $^{126}$.

Projekt Synodu był dla rządu nie do przyjęcia, albowiem pomijał zasadę prymatu ustawodawstwa państwowego nad kościelnym ${ }^{127}$. Podstawą do rokowań stał się aprobowany przez premiera Stanisława Grabskiego projekt MWRiOP. Grabski osobiście podjął rozmowy z metropolitą, który naniósł poprawki do projektu. Po dymisji rządu Grabskiego w listopadzie 1925 r. prace nad projektem kontynuował gabinet Aleksandra Skrzyńskiego. Uzgodniony projekt, który był wyrazem kompromisu, podpisano 14 kwietnia 1926 r. ${ }^{128}$ Po przewrocie majowym prace legislacyjne zostały przerwane, a metropolita 25 maja 1926 r., wykorzystując nadarzającą się okazję, w piśmie do ministra WRiOP oświadczył, że projekt z kwietnia nie

\footnotetext{
123 M. Papierzyńska-Turek, Sprawa ukraińska w Drugiej Rzeczypospolitej 1922-1926, Kraków 1979, s. 275.

124 S. Żeleźniakowicz, Z historii..., „WPAKP” 1983, nr 3, s. 23-24;

M. Papierzyńska-Turek, Sprawa ukraińska..., s. 275.

125 S. Żeleźniakowicz, Z historii..., „WPAKP”, 1983, nr 3, s. 25

126 M. Papierzyńska-Turek, Między tradycją..., s. 158.

127 K. Krasowski, Zwiazki wyznaniowe..., s. 168.

128 M. Papierzyńska-Turek, Między tradycją..., s. 160; K. Krasowski, Związi wyznaniowe..., s. 168
} 
zaspokaja jego oczekiwań i w związku z tym zaproponował wznowienia negocjacji ,na zdrowych podstawach"129.

Kilka tygodni później 1 czerwca Synod podjął decyzję o opublikowaniu opracowanego i przesłanego do MWRiOP w 1925 r. statutu wewnętrznego Kościoła. Z kolei 1 lipca 1926 r. Synod uchwalił projekt ustawy „o stanowisku prawnym Polskiego Autokefalicznego Kościoła Prawosławnego". Projekt ustawy obejmował 30 artykułów i 1 załącznik $^{130}$. Według tego statutu prawosławie w Polsce stanowiło integralną część powszechnego Kościoła prawosławnego. Kościół prawosławny posiadał ustrój autokefaliczny, który był zgodny ze św. kanonami Kościoła i thomosem patriarszym i synodalnym z 1924 r. W statucie stwierdzono, że źródłami prawa kanonicznego Kościoła prawosławnego w Polsce jest Słowo Boże zawarte w Piśmie Świętym, postanowienia soborów powszechnych i święta tradycja. Statut utrzymywał ustrój synodalno-konsystorski tworząc w każdej z pięciu diecezji konsystorz diecezjalny. Konsystorz diecezjalny był ciałem pomocniczym biskupa w sprawach zarząu diecezją i sprawował sądownictwo duchowe. Niższymi instancjami w Kościele pozostawały dekanaty i parafie. Statut określał kompetencje metropolity, biskupów, Synodu, Soboru i innych instytucji cerkiewnych. Statut określał sposób tworzenia bractw cerkiewnych, kształcenia duchowieństwa, funkcjonowania męskich i żeńskich ośrodków zakonnych ${ }^{131}$

Uchwały Synodu wychodziły poza ramy obowiązujących przepisów prawnych, co stronie rządowej dało podstawę do ich odrzucenia ${ }^{132}$. Stanowiska rządu nie zmieniła rozmowa metropolity odbyta 10 lipca $1926 \mathrm{r}$. z marszałkiem Józefem Piłsudskim, podczas której zwierzchnik Kościoła prawosławnego skarżył się na impas w rozmowach z rządem ${ }^{133}$. Za podstawę dalszych rokowań miał służyć projekt ustawy uzgodniony $\mathrm{z}$ metropolitą 14 kwietnia 1926 r. i uzupełniony o te artykuły, na które metropolita nie wyrażał zgody ${ }^{134}$. W tej sytuacji metropolita rozpoczął poszukiwania poparcia wśród wiernych, organizując w styczniu 1927 r. w Poczajowie zjazd przedstawicieli duchowieństwa i świeckich. Zjazd zatwierdził cerkiewny projekt ustawy i statut. Uczestnicy zjazdu 26 marca 1927 r. wystosowali memorandum do rządu, w którym poddano krytyce Tymczasowe przepisy i domagali się unormowania prawnego położenia Kościoła prawosławnego w Polsce. Podobne memoriały zaczęło nadsyłać do MWRiOP duchowieństwo ${ }^{135}$. Z inicjatywy metropolity radca prawny Synodu Konstanty Nikołajew opracował prawne położenie Kościoła prawosławnego w Rzeczypospolitej i wskazał na

\footnotetext{
129 K. Krasowski, Związi wyznaniowe..., s. 169.

130 M. Papierzyńska-Turek, Między tradycja..., s. 161; J. S. Langrod, $O$ autokefalii..., s. 105 .

131 J. S. Langrod, O autokefalii..., s. 109-110.

132 K. Krasowski, Związki wyznaniowe..., s. 169.

133 S. Żeleźniakowicz, Z historii..., „WPAKP”, 1983, nr 3, s. 25-26.

134 M. Papierzyńska-Turek, Między tradycją..., s. 161.

135 Tamże, s. 162-163; A. Mironowicz, Kościót prawosławny na ziemiach polskich w XIX i XX wieku, s. 111-112; tenże, Kościół prawosławny w Polsce, s. 542-543.
}

konieczność nowych regulacji ustawowych ${ }^{136}$. Pod presją takich działań minister WRiOP Kazimierz Świtalski ustalił z metropolitą, że rząd powtórnie rozpatrzy projekt ustawy Synodu z 1926 r., a w razie jego odrzucenia przedstawi własny do lutego 1929 r. ${ }^{137}$ Pomimo zapowiedzi ministra do 1930 r. rząd nie podjął żadnej inicjatywy w tej sprawie.

$\mathrm{Na}$ takie stanowisko rządu wpłynęły postanowienia zjazdu biskupów katolickich, który odbył się 15 lutego 1927 r. we Włocławku. Uczestnicy zjazdu wystosowali pismo do prezesa Rady Ministrów, gdzie wyrażali swoje zaniepokojenie „wiadomościami o toczących się rokowaniach Rządu z Cerkwią prawosławną w Polsce, których wynikiem ma być między innymi zatwierdzenie stanu posiadania Cerkwi prawosławnej u nas". Biskupi łacińscy stwierdzili, że takie uregulowanie nie jest możliwe do przyjęcia, gdyż najpierw należy uregulować sprawy majątkowe z Kościołem katolickim ${ }^{138}$. Rząd uznał stanowisko biskupów katolickich i stwierdził, że ogłoszenie ustawy o stosunku państwa do Kościoła prawosławnego w Polsce odbędzie się dopiero po zakończeniu rokowań z Kościolem katolickim i zawarciu odpowiednich aktów prawnych.

W 1927 r. Synod Kościoła prawosławnego opracował zmiany w cerkiewnej strukturze organizacyjnej dostosowującą ją do podziału administracyjnego państwa. W liście do MWRiOP z 20 lutego 1928 r. metropolita Dionizy postulował, ażeby diecezja wołyńska obejmowała powiaty województwa wołyńskiego, a polesko-pińska - powiaty województwa poleskiego. Biskupstwo wileńskie miało obejmować województwo wileńskie i trzy powiaty województwa nowogródzkiego (wołożyński, lidzki i stołpecki). Eparchia grodzieńska miała się składać z całego terytorium województwa białostockiego i czterech powiatów województwa nowogródzkiego (nowogródzkiego, słonimskiego, baranowickiego i nieświeskiego). Bez zmian miały pozostać granice diecezji warszawsko-chełmskiej ${ }^{139}$. Kancelaria Synodalna w Warszawie przesłała MWRiOP dane, które przedstawiały aktualny stan organizacyjny Kościoła prawosławnego w Polsce i jego stan w poszczególnych diecezjach. Diecezja wołyńska zarządzana przez metropolitę Dionizego i biskupa wikarego krzemienieckiego Szymona (Iwanowskiego) obejmowała województwo wołyńskie, 56 dekanatów, 680 parafii, 8 klasztorów i 850 duchownych. Biskupstwo wileńskie zarządzane przez arcybiskupa Teodozjusza (Fiedosiejewa), obejmowała województwo wileńskie i trzy powiaty województwa nowogródzkiego: wołożyński, lidzki, stołpecki. Diecezja wileńska liczyła 18 dekanatów, 163 parafii, 3 klasztory i 203 księży. Diecezja grodzieńska, kierowana przez arcybiskupa Aleksego (Gromadzkiego), obejmowała województwo białostockie i cztery powiaty województwa nowogródzkiego: nowogródzki, nieświeski, baranowicki i słonimski. Władyctwo posiadało 18 dekanatów, 147 parafii, 3 klasztory i 235 duchownych. Diecezja poleska, zarządzana przez arcybisku-

К. Николаев, Правовое положение Святой Автокефальной Церкви в Польше, Варшава 1927.

137 K. Krasowski, Zwiazki wyznaniowe..., s. 169.

138 S. Żeleźniakowicz, Z historii..., ,WPAKP”, 1983, nr 3, s. 26-27.

139 AAN MWRiOP, nr 1011, k. 32-33. 
pa Aleksandra (Inoziemcowa), obejmowała województwo poleskie. W skład tej eparchii wchodziło 26 dekanatów, 320 parafii, 1 monaster i 357 duchownych. Diecezja warszawsko-chełmska obejmowała resztę terytorium kraju i składała się z 8 dekanatów, 98 parafii, 1 klasztoru i 154 duchownych ${ }^{140}$. Razem Kościół prawosławny w Polsce posiadał 5 diecezji, 126 dekanatów, 1408 parafii etatowych, 16 klasztorów i 1799 duchownych.

Nieco inne dane o liczbie parafii podawały czynniki rządowe. Według władz państwowych Kościół prawosławny w Polsce liczył w 1929 r. 1306 parafii, w tym 994 etatowych ${ }^{141}$. Zmiany terytorialne diecezji wołyńskiej i poleskiej, zaakceptowane na mocy Tymczasowych przepisów przez MWRiOP, ułatwiły administrowanie Kościołem prawosławnym i dostosowały cerkiewną strukturę do potrzeb wiernych. W wyniku tych zmian monaster św. Mikołaja w Mielcu został wyjęty spod jurysdykcji biskupów wołyńskich i podporządkowany pod obediencję ordynariuszy diecezji poleskiej ${ }^{142}$.

Duchowieństwo katolickie, wzmocnione stanowiskiem rządu, masowo wszczęło w 1929 r. procesy rewindykacyjne. Władze Kościoła prawosławnego uświadomiły sobie konieczność zmobilizowania wszystkich sił w obronie swego stanu posiadania. Wobec braku nadziei na porozumienie episkopatu z rządem podjęto decyzję o zwołaniu Soboru Generalnego (krajowego). Sobór Generalny był najwyższą instancja w Kościele prawosławnym, albowiem składał się z hierarchii, przedstawicieli duchowieństwa i wiernych. Postanowienia takiego gremium rząd nie mógł zlekceważyć ${ }^{143}$. Ponieważ zwołanie Soboru Generalnego wymagało w myśl Tymczasowych przepisów akceptacji ze strony rządu, z tego powodu metropolita Dionizy 22 listopada 1929 r. wystosował odpowiednie pismo do ministra WRiOP z prośbą o wyrażenie zgody na jego przygotowanie. Brak odpowiedzi spowodował, że metropolita Dionizy udał się 11 grudnia 1929 r. na osobistą audiencję do ministra, który podczas spotkania nie zgłosił sprzeciwu co do zwołania soboru, jednakże poprosił o wcześniejsze dostarczenie jemu regulaminu i programu soboru ${ }^{144}$. Na drugi dzień Synod uchwalił regulamin Soboru Generalnego, program jego pracy i ustalił terminy wyborów na wszystkich szczeblach organizacji cerkiewnej. Synod wyznaczył termin otwarcia soboru na 12 lutego $1930 \mathrm{r}$. Informację tę 18 grudnia $1929 \mathrm{r}$. kancelaria metropolity podała do prasy, a 21 grudnia przesłano ją dziekanom. W dniu następnym zapowiedź zwołania Soboru Generalnego opublikował organ metropolitalny „Воскресное чтение” z podaniem jego regulaminu i programu ${ }^{145}$. Metropolita Dionizy poinformował również ministra WRiOP Sławomira Czerwińskiego o zamiarze zwołania soboru i poprosił o wyrażenie

\footnotetext{
140 J. S. Langrod, O autokefalii..., s. 110.

141 M. Papierzyńska-Turek, Organizacja..., s. 63.

142 AAN MWRiOP, nr 1011, k. 35-36.

143 S. Kiryłowicz, $Z$ dziejów..., s. 56; Алексий (Громадский) архиепископ, К истории Православной Церкви в Польше..., с. 20; М. Раpierzyńska-Turek, Między tradycją..., s. 164.

144 А. Свитич, Православная Церковь в Польше и ее автокефалия, c. 166-167; J. S. Langrod, O autokefalii..., s. 132-133.

145 M. Papierzyńska-Turek, Między tradycją..., s. 167.
}

zgody na jego przeprowadzenie go w Warszawie. Do pisma metropolita dołączył statut Soboru Generalnego, regulamin i program jego prac.

Kancelaria Departamentu Wyznań MWRiOP otrzymała powyższe dokumenty dopiero 24 grudnia, kiedy już podjęto działania związane z przeprowadzeniem wyborów, bez pisemnej zgody władz państwowych ${ }^{146}$. Sławomir Czerwiński po ukazaniu się $\mathrm{w}$ prasie informacji o soborze, w piśmie z 21 grudnia 1929 r. skierowanym do metropolity Dionizego zabronił przeprowadzania wyborów jego uczestników, polecając jednocześnie wojewodom nie wydawać zezwoleń na odbywanie zebrań parafialnych ${ }^{147}$. Ministerstwo WRiOP wyraziło zastrzeżenia do ordynacji wyborczej, w której widziało zdecydowaną przewagę duchowieństwa nad świeckimi. Zwrócono uwagę na naruszenie Tymczasowych przepisów, w myśl których na zwołanie soboru niezbędna była zgoda MWRiOP ${ }^{148}$. Powstały konflikt wokół zwołania soboru został zażegnany dopiero 10 stycznia 1930 r. po wizycie metropolity u prezydenta Ignacego Mościckiego. W wyniku kompromisu, jaki został zawarty między Synodem a rządem, powołano komisję składającą się z przedstawicieli władz Kościoła prawosławnego i rządu ${ }^{149}$. Komisja ustaliła nowy regulamin i ordynację wyborczą do soboru oraz program prac. Komisja ustaliła, że w przyszłym Soborze Generalnym relacja między duchownymi a świeckimi miała wynosić, jak 2:3, czyli na dwie osoby duchowne przypadały trzy świeckie ${ }^{150}$.

Prace komisji mieszanej doprowadziły w końcu do ogłoszenia 30 maja $1930 \mathrm{r}$. przez prezydenta reskryptu zezwalającego na zwołanie Soboru Generalnego z poprzedzającym go zebraniem przedsoborowym. W reskrypcie prezydent nawiązał do wielowiekowej tradycji Kościoła prawosławnego w Polsce. „Dnia 15 czerwca 1791 r., pod opieką i auspicjami Rządu Najjaśniejszej Rzeczypospolitej Polskiej, został otwarty w mieście Pińsku ostatni Sobór Kościoła Prawosławnego w Polsce. Dzięki wyrokom Opatrzności Bożej, Święty Autokefaliczny Kościół Prawosławny w Polsce może nawiązać nić do swej historycznej przeszłości. Obecnie nadszedł czas, aby urzeczywistnione były dążenia Zwierzchników Kościoła Prawosławnego w osobach śp. Metropolity Jerzego oraz Waszej Ekscelencji jak również Św. Soboru Biskupów i wszystkich obywateli Rzeczypospolitej wyznania prawosławnego, by zgodnie ze Świętymi Kanonami Święty Autokefaliczny Kościół Prawosławny w Polsce odbył swój Sobór, pierwszy w odrodzonym Państwie Polskim"151. Prezydent przesłał również odpowiednie pismo do ministra WRiOP z poleceniem wydania odpowiednich zarządzeń, mających na

\footnotetext{
J. S. Langrod, $O$ autokefalii..., s. 132, przyp. 1.

147 K. Krasowski, Zwiazki wyznaniowe..., s. 171.

148 M. Papierzyńska-Turek, Między tradycja..., s. 168-169.

149 А. Свитич, Православная Церковь в Польше и ее автокефалия, c. 167 i 169; S. Kiryłowicz, $Z$ dziejów..., s. 58.

150 J. S. Langrod, O autokefalii..., s. 133-134; А. Свитич, Православная Церковь в Польше и ее автокефалия, с. 170-171; A. Mironowicz, Kościót prawosławny na ziemiach polskich w XIX i XX wieku, s. 113-114; tenże, Kościót prawosławny w Polsce, s. 545-546.

151 S. Kiryłowicz, Z dziejów..., s. 58-59; J. S. Langrod, $O$ autokefalii...,
} s. 136. 
celu realizację podjętych decyzji152. 31 maja 1930 r. Synod biskupów zatwierdził ustalenia wspólnej komisji w postaci regulaminu i ordynacji wyborczej soboru, a następnie przesłał je ministrowi WRiOP do zatwierdzenia ${ }^{153}$. Synod w Kamieniu Koszyrskim w diecezji poleskiej ustanowił wikariat i obsadził go biskupem lubelskim Antonim (Marcenką).

1 czerwca 1930 r. metropolita Dionizy, w związku $z$ orędziem prezydenta, wydał list pasterski do wiernych, w którym oznajmił o pozytywnej decyzji prezydenta odnośnie zwołania Soboru Generalnego oraz podał ustalony termin zebrania przedsoborowego na 29 czerwca 1930 r. ${ }^{154}$ List pasterski był pełen deklaracji lojalności prawosławia wobec państwa. 2 czerwca 1930 r. orędzie prezydenta zostało uroczyście odczytane w prawosławnej katedrze metropolitalnej św. Marii Magdaleny w Warszawie przez arcybiskupa grodzieńskiego Aleksego w obecności metropolity Dionizego i arcybiskupa Teodozjusza oraz przedstawicieli rządu. Tego samego dnia prezydent podjął na audiencji metropolitę Dionizego i członków Synodu ${ }^{155}$.

Kościół prawosławny był wówczas - poza Kościołem rzymskokatolickim - najliczniejszym związkiem wyznaniowym w Polsce. Według stanu z 1 kwietnia 1930 r. ogólna liczba wierny Kościoła prawosławnego wynosiła 3630 000. Największa liczba wyznawców prawosławia mieszkała na terenie eparchii wołyńskiej - 1300000 . Na obszarze diecezji poleskiej mieszkało - 950000 wiernych, grodzieńskiej - 640000 , wileńskiej - 470000 i warszawskiej - 270000 . Wyznawców prawosławia obsługiwało ponad 1780 duchownych, w tym 180 kapłanów stanu zakonnego. Kościół prawosławny miał 1520 parafii, w tym 1307 etatowych, wspomaganych finansowo przez państwo. W porównaniu z 1927 r. we wszystkich diecezjach, oprócz warszawskiej, zwiększyła się liczba parafii prawosławnych oficjalnie uznawanych przez władze państwowe. Na przykład w diecezji grodzieńskiej ze 147 do 184 . Na terenie wszystkich eparchii z 1408 do $1520^{156}$. W użytkowaniu Kościoła prawosławnego znajdowało się 2400 świątyń, w tym 950 kaplic. Według źródeł rządowych 1 maja 1931 r. na terenie państwa istniały 1497 placówki parafialne, w tym 1306 etatowych i 191 nieetatowych. Cerkiew dysponowała 5 domami biskupimi, 17 klasztorami, 2 seminariami oraz 63188 ha ziemi uprawnej, 16238 ha in-

\footnotetext{
152 M. Papierzyńska-Turek, Między tradycją..., s. 175; J. S. Langrod, $O$ autokefalii..., s. 136-138.

153 J. S. Langrod, $O$ autokefalii..., s. 141-142.

154 Tamże, s. 149; M. Papierzyńska-Turek, Między tradycja..., s. 175-176.

155 J. S. Langrod, O autokefalii..., s. 139-140; А. Свитич, Православная Церковь в Польие и ее автокефалия, с. 185.

156 „Kalendarz Prawosławny” na 1934 r., Tomaszów Lubelski 1934, s. 81. Z kolei wydawany przez Prawosławną Metropolię Warszawską „Kalendarz Prawosławny” na 1931 r. podaje ogólną liczbę 1433 parafii i 3704000 wiernych. W świetle tego źródła diecezja warszawsko-chełmska liczyła 85 parafii, w tym 69 na Chełmszczyźnie i Podlasiu oraz 229000 wiernych. Diecezja wołyńska posiadała 680 parafii i 1238500 wiernych, a eparchia polesko-pińska 319 parafii i 854700 wiernych. Biskupstwo grodzieńsko-nowogródzkie miało w 1930 r. 179 parafii i 648000 wiernych, a wileńsko-lidzkie 170 parafii i 504000 wiernych. „Православный календарь” на 1931 год, Варшава 1930, с. 52-53.
}

nych nieruchomości i 4930 ha lasów. Klasztory dysponowały 1600 ha ziemi ${ }^{157}$. Różnice w danych statystycznych wynikały z przekazania części majątków cerkiewnych Kościołowi katolickiemu w ramach akcji rewindykacyjnej oraz z nieuznawania przez władze państwowe części istniejących parafii.

Pierwsza robocza sesja zebrania odbyła się w dniach 29 czerwca - 3 lipca 1930 r. ${ }^{158} \mathrm{Na}$ sesji zebrania przedsoborowego powołano prezydium, którego przewodniczącym został metropolita Dionizy, wybrano 2 wiceprzewodniczących i 2 sekretarzy. Zapoznano się z regulaminem obrad oraz powołano sześć komisji: religijną, organizacyjno -prawną wewnętrzną, organizacyjno-prawną zewnętrzną, oświatową, wewnętrzną parafialną i życia zakonnego oraz do spraw duchowieństwa prawosławnego ${ }^{159}$. Podstawą do prac komisji stał się referat przewodniczącego wydziału prawnego Synodu Konstantego Nikołajewa o statusie Kościoła prawosławnego w Polsce ${ }^{160}$. Sesję zebrania przedsoborowego zamknął metropolita Dionizy oświadczając, że data następnej sesji będzie ustalona przez prezydium zebrania za zgodą ministra WRiOP w zależności od rezultatów prac $\mathrm{w}$ komisjach ${ }^{161}$. W okresie trwania prac przedsoborowych w episkopacie prawosławnym nastąpiły istotne zmiany. 3 kwietnia 1932 r. dziekan klasztorów diecezji warszawsko-chełmskiej Sawa (Jerzy Sowietow) został wyświęcony na biskupa lubelskiego. 10 kwietnia biskupem wikarym eparchii wołyńskiej z tytułem władyki łuckiego został dziekan klasztorów tej diecezji archimandryta Polikarp (Piotr Sikorski). Konsekracje nowych biskupów wzmocniły episkopat prawosławny, ale nie przyspieszyły prac soborowych.

W trakcie prac soborowych biskupi 20 lipca $1933 \mathrm{r}$. upoważnili metropolitę Dionizego do wystąpienia do rządu Rzeczypospolitej Polskiej w sprawie uchylenia dekretu z 16 grudnia 1918 r. dotyczącego przymusowego zarządu państwowego nad dobrami należącymi do Kościoła prawosławnego. Uchylenie dekretu z 1918 r. dawało Kościołowi prawosławnemu podstawę prawą do żądania zwrotu przejętych przez państwo majątków cerkiewnych. Hierarchia cerkiewna liczyła na przychylne stanowisko rządu nie tylko w tej sprawie, ale i na szybkie uregulowanie prawne położenia Kościoła prawosławnego ${ }^{162}$.

157 AAN, MWRiOP, nr 1157, k. 42.

158 J. S. Langrod, O autokefalii..., s. 150-153; А. Свитич, Православная Церковь в Польше и ее автокефалия, с. 173-174.

159 S. Kiryłowicz, Z dziejów..., s. 59; M. Papierzyńska-Turek, Między tradycją..., s. 179 .

160 К. Николаев, Правовое положение Святой Автокефальной Православной Церкви в Польше, Варшава 1931. (wyd. II).

161 А. Свитич, Православная Церковь в Польше и ее автокефалия, c. 179 .

162 Memorandum J. E. Najbłogosławniejszego ks. Metropolity Dionizego o uchylenie dekretu z dnia 16 grudnia 1918 r. w przedmiocie przymusowego zarządu państwowego, Warszawa 1933. Upoważnienie podpisali metropolita warszawski Dionizy z biskupami wikarymi: lubelskim Sawa, krzemienieckim Szymonem i łuckim Polikarpem oraz pozostali ordynariusze diecezji prawosławnych: wileńskiej - abp Teodozjusz, grodzieńskiej - abp Aleksy, poleskiej - abp Aleksander ze swym biskupem wikarym Antonim rezydującym w Kamieniu Koszyrskim. A. Mironowicz, Kościót prawosławny na ziemiach polskich $w$ XIX i XX wieku, s. 117; tenże, Kościót prawosławny w Polsce, s. 548. 
Prace $\mathrm{w}$ poszczególnych komisjach trwały bardzo wolno. W ciągu pięciu lat tylko komisje religijna, oświatowa, wewnątrzparafialna i życia zakonnego oraz do spraw duchowieństwa podjęły próbę realizacji postawionych im zadań. Natomiast obie komisje organizacyjno-prawne, które miały zaproponować najważniejsze reformy w Kościele, nie podjęły pracy. Pewną inicjatywę w zakresie tematyki prac tych komisji wykazał Synod Biskupów. 1 marca 1934 r. opracował on projekt utworzenia diecezji małopolskiej, która miała obejmować województwo krakowskie, lwowskie, stanisławowskie i tarnopolskie. Prośba metropolity Dionizego o powołanie biskupstwa małopolskiego, wystosowana do MWRiOP, pozostała bez odpowiedzi ${ }^{163}$. Synod, ażeby usprawnić zarządzanie Kościołem, dokonał zmian personalnych $\mathrm{w}$ niektórych diecezjach prawosławnych. 29 marca 1934 r. zarządzającym diecezją grodzieńsko-nowogródzką został bp Antoni (Marcenko). Dotychczasowego władykę grodzieńsko-nowogródzkiego Aleksego Gromadzkiego Synod powołał na ordynariusza diecezji wołyńskiej. Jego wikarym pozostał biskup łucki Polikarp (Sikorski) ${ }^{164}$.

Inaczej sytuacja wyglądała w komisji mieszanej, w której skład wchodzili przedstawiciele władz polskich i hierarchii prawosławnej. W ciągu pięciu lat odbyła ona około stu posiedzeń ${ }^{165}$. W tej sytuacji druga sesja plenarna, obradująca od 12 do 14 maja 1935 r. zakończyła się bez istotnych ustaleń. Podsumowano jedynie dorobek dotychczasowych prac komisji i uzupełniono jej składy. Zadania nie działających komisji organizacyjno-prawnych przejęła komisja mieszana ${ }^{166}$. Prace komisji mieszanej nad projektem ustawy o stosunku państwa do Kościoła prawosławnego w Polsce zostały ukończone 3 grudnia 1936 r., a rozpoczęte 9 marca 1937 r. uzgodnienia z episkopatem prawosławnym sfinalizowano 8 kwietnia. Ostateczna redakcja ustaleń nastąpiła dopiero w styczniu 1938 r., gdy dobiegły końca prace nad ustawą dotyczącą gruntów pounickich.

Sfinalizowanie spraw obrządku greckokatolickiego spowodowało, że rząd wniósł do sejmu projekt ustawy o udzieleniu pełnomocnictw prezydentowi do wydania dekretu o stosunku państwa do Kościoła prawosławnego. Pomimo krytyki projektu ustawy przez środowiska katolickie rząd nie odstąpił od swego stanowiska i po uchwaleniu ustawy o pełnomocnictwach 18 listopada $1938 \mathrm{r}$. prezydent Ignacy Mościcki podpisał dekret o stosunku państwa do Polskiego Autokefalicznego Kościoła Prawosławnego ${ }^{167}$. 7 listopada 1938 r. Synod po zapoznaniu się z projektem dekretu prezydenta uznał, że projekt ten całkowicie odpowiada ustrojowi Kościoła wschodniego i zaspokaja jego interesy. W związku z tym Synod podjął uchwałę, w której stwierdził, że zostało osiągnięte porozumienie, w duchu

\footnotetext{
163 AAN MWRiOP, nr 1011, k. 99-122.

164 А. Свитич, Православная Церковь в Польше и ее автокефалия, c. 156; M. Papierzyńska-Turek, Między tradycją..., s. 217-221.

165 А. Свитич, Православная Церковь в Польше и ее автокефалия, c. $183-184$.

166 S. Kiryłowicz, Z dziejów..., s. 59.

167 K. Krasowski, Związki wyznaniowe..., s. 173-175.
}

obowiązującej konstytucji, władz państwowych z prawną reprezentacją Kościoła. W tym samym dniu Synod przyjął projekt statutu wewnętrznego Kościoła prawosławnego i zdecydował przedłożyć go do akceptacji ministrowi WRiOP ${ }^{168}$.

Dekret z 28 listopada 1938 r. składał się z 85 artykutów i 112 punktów. Do tego dokumentu dodano załączniki, zawierające tekst przysięgi metropolity i biskupów oraz przysięgi członków konsystorza ${ }^{169}$. Dekret stwierdził autokefaliczność Kościoła prawosławnego w Polsce, to znaczy niezależność od władzy pozakrajowej, przy czym „zachowując w sprawach dogmatycznych i kanonicznych jedność z Powszechnym Wschodnim Kościołem Prawosławnym" oraz prawo swobodnego rządzenia się w granicach ustawodawstwa państwowego. Głową Kościoła, jego naczelnym zarządcą i przedstawicielem był metropolita, który był jednocześnie arcybiskupem diecezji warszawskiej i archimandrytą Ławry Poczajowskiej. Metropolita był wybierany na soborze elekcyjnym składającym się ze wszystkich biskupów oraz przedstawicieli duchowieństwa i wiernych. Organem najwyższym Kościoła, regulującym sprawy Polskiego Autokefalicznego Kościoła Prawosławnego, był Sobór Generalny składający się z biskupów oraz przedstawicieli duchowieństwa i świeckich. Sobór Generalny mógł zmienić ustrój Kościoła z dominującego w latach 1918-1938 ustroju synodalno-konsystorskiego, w którym naczelną władzę posiadał Synod biskupów na ustrój soborowy, oparty na zasadach wybieralności episkopatu i dziekanów z czynnym głosem przedstawicieli wiernych. Sobór miał być zwoływany jedynie w sytuacjach wyjątkowych przez metropolitę na podstawie orędzia prezydenta Rzeczypospolitej Polskiej. Rozstrzyganie spraw przekraczających zakres uprawnień biskupów diecezjalnych powierzono Soborowi Biskupów, jako organowi władzy kościelnej, zwoływanego przynajmniej raz w roku.

Organem wykonawczym Soboru Biskupów był Synod składający się z metropolity, który był jego przewodniczącym, biskupa wojskowego i 2 biskupów diecezjalnych wybieranych na dwa lata. Poprzednio Synod składał się ze wszystkich biskupów diecezjalnych. Nowością było wprowadzenie w skład tego gremium biskupa polowego, który był członkiem stałym Synodu. Biskup polowy był powoływany do swej godności przez ministra spraw wojskowych w porozumieniu z metropolitą. Kompetencje Soboru Biskupów w dziedzinie kościelno-religijnej, kościelno-administracyjnej i kościelno-sądowej zostały określone w Statucie Wewnętrznym Polskiego Autokefalicznego Kościoła Prawosławnego ${ }^{170}$. Jednym z zadań Soboru Biskupów był wybór nowych biskupów. Odrębne miejsce zajęły takie ciała kolegialne jak: Główna Komisja Kontrolująca

\footnotetext{
168 Statut wewnętrzny Kościoła prawosławnego w Polsce przygotowała komisja w składzie: metropolita Dionizy, arcybiskup Aleksy i arcybiskup Aleksander. Por.: M. Papierzyńska-Turek, Między tradycją..., s. 183-184. 169 S. Kiryłowicz, Z dziejów..., s. 77. Szczególowe omówienie dekretu z 1938 r., por.: M. Winiarczyk-Kossakowska, Ustawy III Rzeczypospolitej o stosunku państwa do Kościołów chrześcijańskich, s. 75-79.

170 Por.: Statut wewnętrzny Świętego Polskiego Autokefalicznego Kościoła Prawosławnego, Warszawa 1939.
} 
i Diecezjalne Komisje Rewizyjne. Przedstawiciele tych ciał byli wybierani na zebraniach diecezjalnych. Struktura organizacyjna Kościoła zachowała dotychczasowy ustrój i posiadała pion instytucji kolegialnych oraz pion stanowisk indywidualnych. Pion instytucji kolegialnych składał się z Soboru Generalnego, Soboru Biskupów, Synodu Biskupów, zebrań diecezjalnych, konsystorzy diecezjalnych. Konsystorzy diecezjalni składali się z czterech duchownych i jednej osoby świeckiej. Nowością było wprowadzenie w skład konsystorza elementu świeckiego. Osoby świeckie były wybierane na zebraniach diecezjalnych, a następnie zatwierdzane przez biskupa diecezjalnego po upewnieniu się, że wojewoda nie zgłosił wobec nich sprzeciwu. Dekret przewidywał zebrania diecezjalne i parafialne. Omawiany akt prawny zezwolił osobom świeckim na zakładanie bractw na podstawie przepisów o stowarzyszeniach.

Dekret prezydenta ustanawiał grupę stanowisk indywidualnych, do których zaliczano metropolitę, biskupa diecezjalnego, biskupa sufragana, dziekana, proboszcza parafii i wikariusza parafialnego. Kwestie kadrowe ze względu na ich wagę w polityce państwowej wobec Kościoła prawosławnego zostały omówione szczegółowo. Pełnienie urzędów kościelnych uzależniono od posiadania obywatelstwa polskiego. Kandydaci na duchownych powinni mieć ukończoną wyższą uczelnię teologiczną w kraju, z czego mógł zwolnić jedynie minister WRiOP. Wszystkie nominacje i przeniesienia biskupów powinny były uzyskać akceptację ministra WRiOP. Zmiany na stanowisku dziekana, proboszcza i wikarego musiały otrzymać akceptację wojewody. Wszelkie spory między biskupami a wojewodami, powstające $\mathrm{w}$ związku z obsadą urzędu dziekana, proboszcza i wikariusza, rozstrzygał ostatecznie minister WRiOP po zasięgnięciu opinii metropolity. Metropolita był zobowiązany do wstępnego informowania władz państwowych o zamierzonych przez niego wizytacjach parafialnych. Prawo ingerencji władz państwowych w sprawy kościelne występowało w dekrecie w 44 przypadkach, które zostały wymienione w przeszło połowie artykułów tego dokumentu. Od decyzji władzy państwowej zależał sposób załatwiania spraw cerkiewnych.

Kształcenie duchownych odbywać się miało jedynie w państwowym Liceum Teologicznym w Warszawie oraz w Studium Teologii Prawosławnej na Uniwersytecie Warszawskim, a święcenia otrzymywać miały tylko te osoby, które ukończyły wyżej wymienione szkoły. Państwo zobowiązało się utrzymywać państwowy internat dla studentów oraz internat dla uczniów liceum. Kształcenie psalmistów miało odbywać się w szkołach podlegającym ogólnym przepisom państwowym, tzn. ustawie o szkolnictwie prywatnym. Tworzenie nowych klasztorów i przyjmowanie do zgromadzeń klasztornych osób, które odbyły nowicjat lub złożyły śluby zakonne za granicą wymagało zezwolenia ministra oświaty. Obsada przełożonego klasztoru zależała od zgody wojewody. Sprawa duszpasterstwa wojskowego miała całkowicie należeć do kompetencji ministra spraw wojskowych. Prasa cerkiewna miała być wydawana wyłącznie w języku polskim. Tytuły innojęzyczne miały być zamknięte. Duchowni zostali zobligowani do odmawiania podczas nabożeństw modlitw za pomyślność Rzeczypospolitej i jej prezydenta, a w dni świąt państwowych - do odprawiania uroczystych nabożeństw z modłami oraz pieśnią Boże coś Polskę. Dekret niewiele miejsca poświęca sprawom majątkowym Kościoła, odkładając ten problem do odrębnej ustawy. Osobowość prawna została przyznana Kościołowi jako całości organizacyjnej (metropolii), biskupstwom, klasztorom i jednostkom parafialnym. Zapowiedziano reformę rolną $\mathrm{w}$ dobrach prawosławnych, określając normy obszarowe nie podlegające parcelacji. Wynosily one dla metropolii - 180 ha, biskupstwa -150 ha, konsystorzy - 125 ha, klasztorów - 180 ha, każdej świątyni parafialnej w miarę ustalenia jej składu osobowego: na ziemie sieroce -3 ha, dla proboszcza -20 ha, diakona -10 ha, psalmisty -7 ha. Nadwyżki ponad te normy miały być wykupione przez państwo po upływie trzech lat od chwili wejścia w życie dekretu. Ustalono także wysokość miesięcznego uposażenia duchowieństwa, przyznając metropolicie $1075 \mathrm{zł}$ oraz $800 \mathrm{zł}$ na utrzymanie domu metropolitalnego, biskupom diecezjalnym - 700 zł i 500 zł na utrzymanie domu biskupiego, proboszczom - 60 zł, wikariuszom $-35 \mathrm{zl}$ i diakonom $-25 \mathrm{zl}^{.171}$

Dekret z 1938 r. był pierwszy w dziejach prawosławia w II Rzeczypospolitej dokumentem regulującym stosunek państwa do tegoż Kościoła. Omawiany akt prawny znosił powszechnie krytykowany przez duchowieństwo i wiernych stan tymczasowości. Trzeba zaznaczyć, że w świetle takiego uregulowania prawnego Kościół prawosławny został maksymalnie podporządkowany państwu i jego polityce. W trzy tygodnie po wydaniu dekretu, 10 grudnia 1938 r. rozporządzeniem Rady Ministrów został zatwierdzony „Statut Wewnętrzny Polskiego Autokefalicznego Kościoła Prawosławnego"172 ogłoszony w „Dzienniku Ustaw” z 30 grudnia $1938 \mathrm{rr}^{173}$ Statut regulował szczegółowo kompetencje metropolity, Soboru Generalnego, Soboru Biskupów i Synodu Biskupów. Statut określał zasady funkcjonowania zarządów diecezjalnych, dekanatów, parafii, bractw, duszpasterstwa wojskowego i działalność misyjną. Statut unormował sprawy związane z nauczaniem religii i sądownictwem kościelnym ${ }^{174}$. Do „Statutu Wewnętrznego PAKP" dołączono wiele załączników: Ordynacja wyborcza do Soboru Elekcyjnego i zgromadzenia przedelekcyjnego, Ordynacja wyborcza do Soboru Generalnego, Regulamin Soboru Generalnego, Przepisy o Głównej Komisji Kontrolującej, Statut zebrań diecezjalnych PAKP, Regulamin Diecezjalnej Komisji Rewizyjnej, Statut parafialny PAKP, tekst modlitwy za Rzeczpospolitą Polską, Prezydenta i wojsko ${ }^{175}$.

Rozporządzeniem ministra WRiOP z 6 maja 1939 r.

M. Papierzyńska-Turek, Między tradycją..., s. 184-191; S. Kiryłowicz, Z dziejów..., s. 77-79; K. Krasowski, Związi wyznaniowe..., s. 175, 176; A. Mironowicz, Kościót prawosławny na ziemiach polskich w XIX i XX wieku, s. 118-121; tenże, Kościót prawosławny w Polsce, s. 550-552.

172 S. Kiryłowicz, Z dziejów..., s. 77.

173 M. Papierzyńska-Turek, Między tradycja..., s. 193.

174 K. Krasowski, Zwiazki wyznaniowe..., s. 176.

175 Por.: Statut wewnętrzny Świętego Polskiego Autokefalicznego Kościoła Prawosławnego, Warszawa 1939. 
uznano Statut Konsystorzy prawosławnych, który między innymi regulował sposób zarządzania sprawami majątkowymi ${ }^{176} .23$ czerwca $1939 \mathrm{r}$. zatwierdzono ustawę o uregulowaniu stanu prawnego majątków Kościoła prawosławnego i opublikowano ją 30 czerwca 1939 r. w „Dzienniku Ustaw"177. Ustawa ta objęła swoją mocą nieruchomości i prawa rzeczowe, które w dniu 11 listopada 1918 r. należały do osób prawnych Kościoła prawosławnego na obszarze Rzeczypospolitej ${ }^{178}$. Postanowienia ustawy oparto na założeniu uznania stanu posiadania Kościoła w dniu 19 listopada 1938 r., jeżeli to posiadanie było faktyczne i zgodne z rozporządzeniem Komisarza Generalnego z 22 października 1919 r. Za własność Kościoła prawosławnego uznano wszystkie nieruchomości objęte w zarząd państwowy lub przejęte na własność państwa na podstawie ustawy z 17 grudnia 1920 r., jeśli w dniu 19 listopada 1938 r. znajdowały się za wiedzą i bez sprzeciwu władz państwowych w faktycznym władaniu osób prawnych Kościoła. W posiadaniu Kościoła prawosławnego pozostawiono ponad 52 200 ha gruntów ze 146000 ha, jakie posiadał przed zastosowaniem dekretu z 16 grudnia 1918 r. ${ }^{179}$

Unormowaniu spraw prawno-majątkowych w $1938 \mathrm{r}$. towarzyszyło zlikwidowanie ponad 127 prawosławnych obiektów sakralnych na Chełmszczyźnie i Podlasiu. Radykalne zmniejszenie się liczby parafii na terenie diecezji warszawsko-chełmskiej spowodowane zniszczeniem cerkwi zaniepokoiło władze cerkiewne. W tej sytuacji Synod Biskupów 7 listopada 1938 r. podjął decyzję o zmianie granic diecezji metropolitalnej. Władze państwowe zaakceptowały ten plan czując się współwinne ostatniej bezmyślnej akcji rewindykacyjnej. W rezultacie decyzji Synodu do diecezji warszawsko-chełmskiej przyłączono część władyctwa grodzieńskiego (powiat Brześć) i wołyńskiego (powiaty Kowel i Luboml). Parafie położone na terenie wymienionych powiatów zasiliły stan biskupstwa metropolitalnego ${ }^{180}$.

Ostateczne zmiany w episkopacie prawosławnym nastąpily w latach 1937-1938. 27 lutego 1937 r. Synod przeniósł biskupa lubelskiego Sawę na katedrę grodzieńsko-nowogródzką. Pod presją władz państwowych na biskupów wyświęcono dwóch propolsko nastawionych duchownych - 27 listopada 1938 r. Jerzego Szrettera (bp. Tymoteusza) i 29 listopada 1938 r. Konstantego Siemaszkę (bp. Mateusza). Akcja polonizacyjna prowadzona przez bp. Mateusza na terenie diecezji wileńskiej wywołała powszechne oburzenie ludności prawosławnej. Podobną działalność polonizacyjną prowadzili bp Tymoteusz na terenie eparchii warszawsko-chełmskiej i bp Sawa w diecezji grodzieńsko-nowogródzkiej ${ }^{181}$. W 1939 r. diecezją war-

\footnotetext{
176 K. Krasowski, Zwiąki wyznaniowe..., s. 176, przyp. 204.

177 M. Papierzyńska-Turek, Między tradycją..., s. 193.

178 S. Kiryłowicz, Z dziejów..., s. 82.

179 K. Krasowski, Związki wyznaniowe..., s. 176; M. Papierzyńska-Turek, Między tradycją..., s. 393.

180 „Wiadomości Metropolii Prawosławnej w Polsce”, nr 2, 1938, s. 1; nr 1,1939 , s. 1.

181 И. Касьяк, З гистории Праваслаунай Царквы Беларускага народу, New York 1956, s. 68-69; Tenże, Byelorussia. Historical Outline, London 1989, pp. 164-167.
}

szawsko-chełmską kierował metropolita Dionizy, któremu pomagał biskup wikary z tytułem władyki lubelskiego Tymoteusz. Ordynariuszem eparchii grodzieńsko-lidzkiej był bp Sawa, a wileńsko-lidzkiej abp Teodozjusz. Abp. Teodozjuszowi pomagał konsekrowany władyka brasławski Mateusz. Diecezją polesko-pińską zarządzał abp Aleksander. Abp Aleksy był ordynariuszem władyctwa wołyńsko-krzemienieckiego.

Po zmianach terytorialnych $\mathrm{w}$ granicach diecezji warszawsko-chełmskiej, grodzieńsko-nowogródzkiej i wołyńskiej zmienił się stan posiadania w poszczególnych eparchiach. Liczba parafii zmniejszyła się w wyniku przeprowadzonych akcji rewindykacyjnych i burzenia cerkwi na Chełmszczyźnie i Podlasiu. Liczba parafii w diecezji grodzieńskiej zmniejszyła się z $200 \mathrm{w} 1938$ r. do 154 w 1939 r. Po odłączeniu powiatów Kowel i Lubolm diecezja wołyńska straciła na rzecz warszawskiej 113 parafii. Natomiast na terenie biskupstwa warszawsko-chełmskiego, pomimo strat poniesionych w czasie akcji burzenia cerkwi, w wyniku zmiany granic diecezji liczba parafii wzrosła ze 161 (dane z 22 stycznia 1938 r.) do 258 w 1939 r. $\mathrm{Na}$ terenie eparchii wileńsko-lidzkiej nastąpił nieznaczny spadek liczby parafii ze 175 do 173 . Nie zmienił się stan posiadania na terenie diecezji poleskiej (341 parafii) ${ }^{182}$. Według oficjalnych danych statystycznych Kościół prawosławny w końcu 1938 r. obejmował 1 metropolię, 5 diecezji, 2 seminaria duchowne z 202 alumnami, Studium Teologii Prawosławnej w Warszawie, 340 dekanatów, 1160 parafii i 1792 duchownych ${ }^{183}$. Struktura diecezjalna nie pokrywała się z podziałami administracyjnymi państwa. Diecezja grodzieńsko-nowogródzka obejmowała województwo białostockie (bez powiatów Łomża, Ostrołęka, Ostrów, Szczuczyn, Wysokie Mazowieckie i Bielsk Podlaski) i część nowogródzkiego (powiaty Baranowicze, Nieśwież, Nowogródek i Słonim). Władyctwo polesko-pińskie objęło województwo poleskie (bez powiatu Brześć) i część wołyńskiego (powiat Sarny). Biskupstwo wileńsko-lidzkie rozciągało się na terenie województwa wileńskiego i części nowogródzkiego (powiaty Lida, Stołpce, Szczuczyn i Wołożyn). Diecezja wołyńska swym zasięgiem obejmowała większość województwa wołyńskiego (bez powiatów Kowel, Luboml i Sarny). W skład eparchii warszawsko -chełmskiej wchodziło województwo pomorskie, poznańskie, warszawskie, łódzkie, śląskie, krakowskie, kieleckie, lwowskie, stanisławowskie, tarnopolskie i lubelskie oraz część wołyńskiego (powiaty Kowel i Luboml), poleskiego (powiat Brześć), białostockiego (powiat Bielsk Podlaski).

Pod względem liczebności społeczność prawosławna była drugą grupą wyznaniową w Polsce. Według źródeł oficjalnych 1 stycznia 1939 r. na terytorium kraju mieszkało 4195000 wyznawców prawosławia. W porównaniu ze spisem ludności z 1937 r. liczba ludności tego wyznania wzrosła o 432500 osób. Większość wyznawców Kościola prawosławnego przebywała we wschodnich regionach

\footnotetext{
182 Prawosławne Archiwum Metropolitarne, RVI-3B, nr 1308; K. Urban, Kościót prawosławny u schyłku II Rzeczypospolitej, „Церковный Вестник”, нр. 12, 1995, с. 16; нр. 8, 1996, с. 20-21; нр. 9, 1996, с. 11-21. 183 B. Kumor, Historia Kościoła, t. VIII, Lublin 2001, s. 426.
} 
państwa. Zwarte skupiska społeczności prawosławnej znajdowały się na 37,4\% terytorium Polski. Źródła cerkiewne informują, że w 1939 r. na terenie diecezji grodzieńsko-nowogródzkiej mieszkało 660400 prawosławnych, polesko -pińskiej - 972 600, warszawsko-chełmskiej - 821 200, wileńsko-lidzkiej - 544600 i wołyńskiej - 1196200. W stosunku do ogółu ludności danego obszaru najwyższy wskaźnik prawosławnych występował na terenie powiatów Drohiczyn, Kobryń, Kosów, Kamień Koszyrski, Stolin i Krzemieniec (ponad 80\%) oraz Łuniniec, Pińsk, Prużany, Sarny, Dubno, Horochów, Zdołbunów, Nieśwież, Nowogródek, Słonim, Mołodeczno, Wilejka, Kowel i Luboml (70-80\%). Od 60\% do 70\% ogółu mieszkańców stanowili prawosławni w powiatach Kostopol, Łuck, Równe, Baranowicze, Wołkowysk, Dzisna, Postawy i Bielsk Podlaski. W pozostałych powiatach województw wschodnich ludność prawosławna stanowiła od $5 \%$ do $60 \%$ ogółu mieszkańców. Duże skupiska społeczności prawosławnej były na Łemkowszczyźnie (Jasło, Gorlice, Krosno, Nowy Sącz, Sanok) oraz w Warszawie, Wilnie, Łodzi, Kaliszu, Lwowie i Kołomyi ${ }^{184}$.

184 „Wiadomości Metropolii Prawosławnej w Polsce”, nr 3 (11), 1939, s. 6-7; K. Urban, Kościót prawostawny u schyłku II Rzeczypospolitej,
Powyższe dane liczbowe potwierdzają wzrost liczby wiernych wyznania prawosławnego $\mathrm{w}$ ostatnich latach II Rzeczypospolitej. Wzrost ten nastapił pomimo prowadzonych akcji rewindykacyjnych i neounijnych. Skutki tych akcji rekompensował przyrost naturalny oraz powrót do prawosławia ludności łemkowskiej na Podkarpaciu i ukraińskiej na terenie Małopolski. Prowadzona na tych terenach działalność misyjna Kościoła prawosławnego spowodowała, że kilka tysięcy ludności wyznania greckokatolickiego powróciło do prawosławia. Tylko na terenie diecezji metropolitalnej liczba wiernych wzrosła z 736601 w 1931 r. do 821200 w 1939 r ${ }^{185}$.

„Церковный Вестник”, нр. 12, 1995, с. 12-13; A. Mironowicz, Kościót prawosławny na ziemiach polskich w XIX i XX wieku, s. 122-124; tenże, Kościót prawosławny w Polsce, s. 553-555.

185 W. Kosonocki, Liczba i rozmieszczenie ludności prawosławnej w Polsce, „Wiadomości Metropolii Prawosławnej w Polsce”, 1939, nr 3 (11), s. 6-7; W. Mysłek, Przedmurze. Szkice z dziejów Kościoła katolickiego w II Rzeczypospolitej, Warszawa 1987, s. 142-61; A. Mironowicz, Ks. Michat Bożerianow i jego odpowiedź , Ludziom matym ”, Białystok 2015, s. 16-19; R. Dubec, Z dziejów parafii prawosławnych na Łemkowszczyźnie w okresie międzywojennym, Gorlice 2011.

\section{Bibliografia}

Bendza M., Autokefalia Kościoła prawostawnego w Polsce,

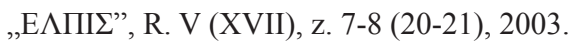

Bobowski K., Szkice z dziejów prasy Kościoła prawosławnego w Polsce w latach 1918-1939, [w:] „Chrześcijanin a współczesność", nr 2, 1985.

Borkowski A., Między Konstantynopolem a Moskwą. Źródta do dziejów autokefalii Kościoła prawosławnego w Rzeczypospolitej (1919-1927), Białystok 2015.

Buławski R., Projekt drugiego spisu powszechnego na tle doświadczeń spisu z 1921 r., „Kwartalnik Statystyczny”, 1930, z. 1 .

Dubec R., Z dziejów parafii prawosławnych na Łemkowszczyźnie w okresie międzywojennym, Gorlice 2011.

Dudra S., Metropolita Dionizy (Waledyński) 1876-1960), Warszawa 2010.

Friszke A., Kościoły wschodnie w Drugiej Rzeczpospolitej, „Więź” 1988, nr 7-8.

Gomółka K., Białorusini w II Rzeczypospolitej, „Zeszyty Naukowe Politechniki Gdańskiej. Ekonomia”, t. XXXI, Gdańsk 1992.

Gomółka K., Próby białorutenizacji Kościoła Prawosławnego w Polsce międzywojennej, „Obóz” 1992, nr 23.

Grzesiak K., Diecezja lubelska wobec prawostawia w latach 1918-1939, Lublin 2010;

Historia Polski w liczbach. Ludność i terytorium (GUS), Warszawa 1993.

Kania J., Rozbiórki cerkwi na Lubelszczyźnie w roku 1938 a stanowisko biskupa Fulmana, [w:] Chrześcijański wschód a kultura polska, pod red. R. Łużnego, Lublin 1989.
Kasiak I., Byelorussia. Historical Outline, London 1989.

Kiryłowicz S., Niektóre problemy prawosławia na tle polityki wyznaniowej państwa w okresie międzywojennym, „Posłannictwo", nr 3-4 (1979).

Kiryłowicz S., Z dziejów prawosławia w II Rzeczypospolitej Polskiej. Niektóre problemy na tle polityki wyznaniowej państwa 1918-1939, Warszawa 1985.

Kiryłowicz S., Z dziejów prawosławia w II Rzeczypospolitej Polskiej. Niektóre problemy na tle polityki wyznaniowej państwa w 1918-1939, „WPAKP”, 1986, nr 2.

Kosonocki W., Liczba i rozmieszczenie ludności prawosławnej w Polsce, „Wiadomości Metropolii Prawosławnej w Polsce", 1939, nr 3 (11).

Kościót prawosławny w Polsce dawniej i dziś, pod red. L. Adamczuka i A. Mironowicza, Warszawa 1993.

Krasowski K., Zwiąki wyznaniowe w II Rzeczypospolitej. Studium historyczno-prawne, Warszawa 1988.

Kumor B., Historia Kościoła, t. VIII, Lublin 2001.

Langrod S. J., O autokefalii prawostawnej w Polsce. Studium z zakresu polskiej polityki administracji wyznaniowej, Warszawa 1931.

Lenczewski M., Studium Teologii Prawosławnej na Uniwersytecie Warszawskim w latach 1925-1939, Warszawa 1992.

Lenczewski M., Z historii światyń prawosławnych $w$ Warszawie, „Wiadomości PAKP”, 1976, z. 3-4.

Łomacz B., Neounia, „Więź”, 1983, nr 1.

Łomacz B., Praca duszpasterska duchowieństwa neounickiego, „Novum” 1980, nr 5.

Łotocki, Autokefalia. Zasady Autokefalii, Warszawa 1932. 
Mackiewicz-Cat S., Historia Polski od 11 listopada 1918 r. do 17 września 1939 r., London 1941.

Mędrzecki W., Liczebność i rozmieszczenie grup narodowościowych w II Rzeczypospolitej w świetle wyników II spisu powszechnego (1931), „Dzieje Najnowsze” 1983, nr 1/2;

Mironowicz A., Białoruskie wydawnictwa cerkiewne w II Rzeczypospolitej, [w:] Między Rzymem a Nowosybirskiem. Księga Jubileuszowa dedykowana Ks. Marianowi Radwanowi SCJ, red. I. Wodzianowska i H. Łaszkiewicz, Lublin 2012-2013.

Mironowicz A., Bractwa cerkiewne w Rzeczypospolitej, Białystok 2003.

Mironowicz A., Cerkiew prawosławna a białoruska świadomość narodowa, „Белорусский сборник”, Статьи и материалы по истории и культуре Белоруссии, вып. ІІ, Санкт-Петербург 2002.

Mironowicz A., Cerkiew prawosławna $w$ dawnej $i$ we wspótczesnej Rosji, [w:] Bizancjum - Prawosławie - Romantyzm. Tradycja wschodnia w kulturze XIX wieku, pod red. J. Ławskiego i K. Korotkicha, Białystok 2004.

Mironowicz A., Destroying and revindication of Orthodox church in Poland in 1937-1939, „Administracja Publiczna. Studia krajowe i międzynarodowe. Zeszyty Naukowe Wyższej Szkoły Administracji Publicznej w Białymstoku", Białystok 2006, nr 1 (7).

Mironowicz A., Jozafat Dubieniecki. Historia cudownego obrazu żyrowickiego, „Zeszyty Naukowe KUL”, R. XXXIV, nr 1-2 (133-134), Lublin 1994.

Mironowicz A., Kościót prawosławny na ziemiach polskich w XIX i XX wieku, Białystok 2005.

Mironowicz A., Kościót prawosławny w dziejach dawnej Rzeczypospolitej, Białystok 2001.

Mironowicz A., Kościót prawosławny w Polsce, Białystok 2016.

Mironowicz A., Ks. Michat Bożerianow i jego odpowiedź „Ludziom małym", Białystok 2015;

Mironowicz A., Ks. Michał Bożerianow, jego życie i działalność, [w:] 20 - lecie restytucji Prawostawnego Ordynariatu Wojska Polskiego, pod red. J. Pańkowskiego, Warszawa 2015.

Mironowicz A., L'Église orthodoxe en Pologne au XX siècle, [in:] L' Église orthodoxe en Europe orientale au XX siècle, sous la direction de Christine Chaillot, Paris 2009.

Mironowicz A., Monaster św. Onufrego w Jabłecznej, „Białoruskie Zeszyty Historyczne", nr 9, Białystok 1998.

Mironowicz A., Monastery prawostawne na terenie diecezji chetmsko-betskiej, [w:] Zakony i klasztory w Europie Środkowo -Wschodniej. X-XX wiek., pod red. H. Gapski, J. Kłoczowski, Lublin 1999.

Mironowicz A., Neounia w II Rzeczypospolitej, [w:] Kościót Greckokatolicki na Warmii i Mazurach, red. M. Melnyk, Olsztyn 2006.

Mironowicz A., Prasa prawosławna w II Rzeczypospolitej, [w:] Literatura. Pamięć. Kultura. Prace ofiarowane Profesor Elżbiecie Feliksiak, red. E. Sidoruk i M. M. Leś, Białystok 2010;

Mironowicz A., Prawosławne szkolnictwo cerkiewne, „ReligiaEncyklopedia PWN", pod red. T. Gadacza i B. Milerskiego, t. VIII, Warszawa 2003.

Mironowicz A., Prawosławne szkolnictwo teologiczne na terenie Rzeczypospolitej, [w:] Od Kijowa do Rzymu. Z dziejów stosunków Rzeczypospolitej ze Stolica Apostolską i Ukraina, pod red. M. R. Drozdowskiego, Białystok 2012.

Mironowicz A., Prawosławne szkolnictwo teologiczne na terenie Rzeczypospolitej, „Wiadomości PAKP”, nr 7-8 (140-141), Warszawa 2001, s. 13-19.

Mironowicz A., Problem narodowościowy w Cerkwi prawosławnej II Rzeczypospolitej, „Przegląd Wschodni”, Warszawa 2014, t. XIII, z. 2 (50).

Mironowicz A., Problematyka narodowościowa w Kościele prawosławnym w II Rzeczypospolitej, [w:] W kręgu sacrum i pogranicza, pod red. E. Matuszczyk i M. Krzywosza, Białystok 2004.

Mironowicz A., Przycinek do dziejów Polskiego Prawosławnego Duszpasterstwa Cywilnego na emigracji w czasie II wojny światowej, „Studia Polonijne”, t. XXX, Lublin 2009-2010.

Mironowicz A., Rewindykacja i niszczenie prawosławnych obiek-

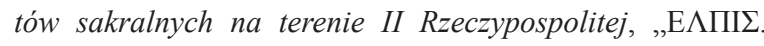
Czasopismo Katedry Teologii Prawosławnej Uniwersytetu w Białymstoku", Białystok 2006, R. VIII (XIX), z. 13-14 (26-27).

Mironowicz A., Rewindykacja prawostawnych obiektów sakralnych w II Rzeczypospolitej, ,Białoruskie Zeszyty Historyczne", nr 21, Białystok 2004.

Mironowicz A., Szkolnictwo prawostawne w Rzeczypospolitej, [w:] Szkolnictwo prawostawne w Rzeczypospolitej, pod red. A. Mironowicza, U. Pawluczuk, Białystok 2002.

Mironowicz A., Światynie prawostawne na terenie miasta Biategostoku, „Białostocki Przegląd Kresowy”, t. VI, pod red. J. F. Nosowicza, Białystok 1998.

Mironowicz A., The Destruction and Transfer of Orthodox Church Property in Poland, 1919-1939, „Polish Political Science Yearbook", Torun 2014, vol. XLIII.

Mironowicz A., The Orthodox Church in Poland in the Twentieth Century, [in:] The Orthodox Church in Eastern Europe in Twentieth Century, ed. Christine Chaillot, Oxford - Bern 2011.

Mironowicz A., Wyznania a świadomość narodowa Białorusinów, „Białostockie Teki Historyczne”, Białystok 2011.

Mironowicz A., Życie monastyczne na Podlasiu, Białystok 1998.

Mironowicz A. Życie monastyczne w dawnej Rzeczypospolitej, [w:] Życie monastyczne w Rzeczypospolitej, pod red. A. Mironowicza, U. Pawluczuk, Białystok 2001.

Moroz M., „Krynica” Ideologia białoruskiego katolicyzmu, Białystok 2001.

Mróz M., Katolicyzm na pograniczu. Kościół katolicki wobec kwestii ukraińskiej i białoruskiej w Polsce w latach 1918-1925, Toruń 2003.

Mysłek W., Przedmurze. Szkice z dziejów Kościoła katolickiego w II Rzeczypospolitej, Warszawa 1987.

Odziemkowski J., Stużba duszpasterska Wojska Polskiego 1914-1945, Warszawa 1998.

Odziemkowski J., Frątczak S., Polskie duszpasterstwo wojskowe, Warszawa 1996.

Odziemkowski J., Spychała B., Duszpasterstwo wojskowe w Drugiej Rzeczypospolitej, Warszawa 1987.

Paczkowski A., Prasa polska w latach 1918-1939, Warszawa 1980. 
Papierzyńska-Turek M., Chcieli prawostawie w Polsce wykorzenić, „Przegląd Prawosławny” nr 7, 1998.

Papierzyńska-Turek M., Między tradycją a rzeczywistością. Państwo wobec prawostawia 1918-1939, Warszawa 1989.

Papierzyńska-Turek M., Organizacja Kościoła Prawosławnego w latach 1918-1939, [w:] Kościót Prawosławny w Polsce dawniej $i$ dziś. pod red. L. Adamczuka i A. Mironowicza, Warszawa 1993.

Papierzyńska-Turek M., Problem autokefalii Kościoła prawosławnego w Polsce $w$ latach 1918-1939, „Euhemer - Przegląd Religioznawczy", nr 1-3, 1980.

Papierzyńska-Turek M., Sprawa ukraińska w Drugiej Rzeczypospolitej 1922-1926, Kraków 1979.

Papierzyńska-Turek M., Spory i konflikty wokół sprawy narodowego charakteru Kościoła prawostawnego w II Rzeczypospolitej, [w:] Trudna tożsamość. Problemy narodowościowe i religijne w Europie Środkowo-Wschodniej w XIX i XX wie$k u$, pod red. J. Lewandowskiego, Lublin 1996.

Pawluczuk U., Ławra Poczajowska. Pod opieka Matki Bożej i św. Hioba, Białystok 2013.

Pawluczuk U., Życie monastyczne w II Rzeczypospolitej, Białystok 2007.

Pawluczuk U., Życie monastyczne w II Rzeczypospolitej, [w:] Kościót prawosławny $w$ dziejach Rzeczypospolitej i krajów sasiednich, pod. red. P. Chomika, Białystok 2000.

Pelica G. J., Kościół prawosławny w województwie lubelskim (1918-1939), Lublin 2007.

Pietrzak M., Reglamentacja wolności prasy w Polsce (1918-1939), Warszawa 1963.

Piotrowski S., Wojna religijna na kresach, Warszawa 1930.

Pirożyński M., Statystyka Kościoła w Polsce, Lublin 1935.

Prawosławne oficyny wydawnicze w Rzeczypospolitej, pod red. A. Mironowicza, U. Pawluczuk, Białystok 2004.

Rzemieniuk F., Kościól katolicki obrządku bizantyjsko-słowiańskiego. Neounia, Lublin 1999;

Sawicki D., Wyższe szkolnictwo teologiczne Cerkwi prawosławnej w odrodzonej Rzeczypospolitej, „Cerkiewy Wiestnik,”, nr 2, 2018.

Sawicki J., Studia nad położeniem prawnym mniejszości religijnych w państwie polskim, Warszawa 1937.

Siemakowicz M., Spisy ludności a zagadnienia narodowościowe z uwzględnieniem spraw szkolnictwa dla mniejszości białoruskiej w II Rzeczypospolitej, „Białoruskie Zeszyty Historyczne", 1998, nr 10.

Sokoł K., Sosna A., Kopuly nad Wisła. Prawostawne cer$k w i e$ centralnej Polsce $w$ latach 1815-1915, Moskwa 2003.

Srokowski K., Sprawa narodowościowa na kresach wschodnich, Kraków 1924.

Staszewski M. T., Mniejszości wyznaniowe w II Rzeczypospolitej, „Zeszyty Argumentów” 1967, nr 3.

Staszewski M. T., Wolność sumienia przed trybunatem II Rzeczypospolitej, Warszawa 1970.

Staszewski M. T., Wolność sumienia w II Rzeczypospolitej (Szkic zagadnienia), „Posłannictwo” 1986, nr 3-4.

Szkolnictwo prawosławne w Rzeczypospolitej, pod red. A. Mironowicza, U. Pawluczuk, Białystok 2002.

Świątkowski H., Niektóre aspekty prawne stosunku państwa do wyznań w Polsce przedwrześniowej, „Państwo i Prawo” 1959, nr 1 .

Świątkowski H., Status prawny Polskiego Autokefalicznego Kościoła Prawosławnego, Warszawa 1939.

Świątkowski H., Wyznania religijne $w$ Polsce, ze szczególnym uwzględnieniem ich stanu prawnego, cz. I, Wyznania i związki religijne, Warszawa 1937.

Światynie prawosławne w Polsce, pod red. A. Burskiego, B. Jewsiewickiego i K. Trufanoffa, Warszawa 1933.

Tomaszewski J., Ojczyzna nie tylko Polaków. Mniejszości narodowe w Polsce w latach 1918-1939, Warszawa 1985.

Traczuk J., Książka białoruska w II Rzeczypospolitej 1921-1939, Warszawa 2000.

Traczuk J., Prasa białoruska w II Rzeczypospolitej (1918-1939), „Studia Polono-Slavica-Orientalia. Acta Litteraria”, t. XIII, Warszawa 1992.

K. Urban, Kościót prawosławny u schytku II Rzeczypospolitej, „Церковный Вестник”, нр. 12, 1995; нр. 8, 1996; нр. 9, 1996.

Urban K., Prawosławni w strukturze wyznaniowej Polski, [w:] Kościół prawosławny w Polsce. Dawniej i dziś, pod red. L. Adamczuka i A. Mironowicza, Warszawa 1993.

Urbański Z., Mniejszości narodowe w Polsce, Warszawa 1933.

Waszkiewicz Z., Duszpasterstwo w siłach zbrojnych Drugiej Rzeczypospolitej (1918-1939), Torun 2000.

Waszkiewicz Z., Neounia - nieudany eksperyment?, [w:] Czterechsetlecie zawarcia unii brzeskiej 1596-1996, pod red. St. Alexandrowicza i T. Kempy, Torun 1998;

Winiarczyk-Kossakowska M., Ustawy III Rzeczypospolitej o stosunku państwa do Kościołów chrześcijańskich, Warszawa 2004.

Wróblewski W., Duszpasterstwo mniejszości religijnych $w$ Wojsku Polskim w latach 1918-1939, [w:] Biatoruś, Czechostowacja, Litwa, Polska, Ukraina. Mniejszości w świetle spisów statystycznych XIX-XX w., pod red. J. Skarbka, Lublin 1996.

Wyczawski H. E., Cerkiew prawosławna w II Rzeczypospolitej, [w:] Kościót w II Rzeczypospolitej, Lublin 1980.

Wyczawski H. E., Ruch neounijny w Polsce w latach 1923-1939, „Studia Theologica Varsoviensia”, t. VIII, 1970, nr 1.

Wyszomirski T., Kościót prawosławny w Polsce w latach 1918-1939, „Novum” 1980, nr 3.

Zyzykin M., Autokefalia i zasady jej zastosowania, Warszawa 1931.

Żeleźniakowicz S., Z historii Polskiego Kościoła Prawosławnego w okresie międzywojennym (1918-1939), „Wiadomości Polskiego Autokefalicznego Kościoła Prawosławnego”, 1981, nr 4, 1982, nr 1, 2, 3-4, 1983, nr 1-2, 3, 4.

Алексий (Громадский) архиепископ, К истории Православной Церкви в Польше за десятилетие пребывания во главе её Блаженнейтего Митрополита Дионисия (1923-1933), Варшава 1937.

Алексий (Громадский) архиепископ, О каноничности «Положения о внутреннем устройстве Православной Церкви в Польше», Варшава 1927.

Асіпчык А. А., Жыровічы: гістарычны нарыс, Кліўленд 1980. Бантыш-Каменский Н. Н., Историческое известие о возникшей в Польше унии, Москва 1805. 
Біднов В., Церковна справа в Украйні, Тарнів 1921.

Борщевич В., Украйнське иерковне відродження на Волині (20-40-mi pp. XX cm.), Луцьк 2000.

Грушевський М., Історія Украӥни-Руси, т. VII, Київ-Львів, 1909.

Давидюк М., Справа беларусізащі Правослаӯнай царквы $\bar{y}$ святле палітыкі дзяржаӯных улад 1919-1939, „Беларускі каляндар", Беласток 1990.

Данілічева В., До історії шкільництва Рівного в міжвоєнний період (20-30 mi pp. XX cm.): Наукові записки Рівненського обласного краєзнавчого музею, Випуск IV. (Матеріали наукової конференції 25-26 жовтня 2006р.), Рівне 2006.

Дениско Л., Релігійні православні періодичні видання XIX початку XX століття у фондах національної бібліотеки України імені В. І. Вернадського: Каталог. Наук. ред. О. С. Онищенко, Київ 2001.

Дорош Н., Митрополит Пантелеимон (Рожновский 18671950), „Беларускі Православный календарь” на 2003 год, Мінск 2002.

Дорош Н., Православный Гродно, Гродно 2000.

Дорошенко Д., Нарис історії України, т. I-II, Варшава 1932$-1933$.

Железякович С., Яблочинский монастырь в межвоенный период 1918-1939, „Церковный Вестник”, нр 4-6, Варшава 1983.

Жилюк С. І., Російська православна иерква на Волині (17931917), Житомир 1996.

Жировичская чудотворная икона Божьей Матери и Жировичская обитель, Вильно 1867.

Зелинский В., Очерки по истории Почаевской Лавры, Почаевская Лавра 2000.

Карташев А. В. , Жизненный путь Митрополита-Экзарха Владимира. К пятидесятилетию архиерейской хиротонии, Париж 1957.

Касьяк И., $З$ гистории Праваслаунай Царквы Беларускага народy, New York 1956.

Косик В. И., Владимир „Православная энциклопедия”, т. VIII, Москва 2004.

Косоноцкый В., Процес за Правосавні Церкви, ч. 1, Варшава 1930.

Кривова Н. А., Власть и иеерковь в 1922-1925 г2.: Политбюро и ГПУ в борьбе за церковные цеенности и политическое подчинение духовенства, Москва 1997.

Купранець О. Ф., Православна церква в міжвоєнній Польщі, 1918-1939, „Analecta OSBM”, vol. XXXI, Рим 1974.

Лотоцький О., Українські джерела церковного права, Варшава 1931.

Мартинюк М., Українські періодичні видання Західної України, країн Центральної та Західної Європи (1914-1939 рр.): Матеріали до бібліографї, Львів 1998.
Миронович А., Неоуния в Польше в межвоенной период, „Вестник Екатеринбургской духовной семинарии”, Екатеринбург 2013, вып. 2 (6).

Миронович А., Ревиндикачия православных ичерквей в II Речи Посполитой, „Православие в Балтии”, нр 4 (13), Riga 2016.

Миронович А., Светские православные организации в послевоенной Польше, „Seminarium Hortus Humanitatis”, vol. XV, Riga 2008.

Митрополит Владимир, святитель и молитвенник (18731959), Париж 1965.

Николаев К., Правовое положение Святой Автокефальной Церкви в Польше, Варшава 1927.

Православная Вольнь, Кременец 1933.

Православные русские обители, Санкт-Петербург 1913.

Огієнко I., Мова українська була вже мовою иеркви, Тарнів 1921.

Огієнко І., Нариси з історії украӥнської мови: система українського правопису, Варшава, 1927.

Огієнко І., Підвалині Украӥнської православної ичеркви, Тарнів 1922.

Рожко В., Нарис історії Украӥнської Православної Церкви на Волині (870 - 2000), Луцьк 2001;

Рожко В., Православні монастирі Волині, Луцьк 1997.

Романюк М. М., Періодика Західної України 20-30-х рр. ХХ ст.: матеріали до бібліографії у 5 m. (1998-2003). Львів 2008-2010. т. І, Львів 1998.

Свитич А., Православная Церковь в Польше и ее автокефалия, Буэнос-Айрес, 1959.

Свитич А., Православная Церковь на Украине и в Польше в ХХ столетии: 1917-1950 гг., Москва 1997.

Сіповіч Ч., Пралат Пётр Татарьтовіч, [в:] Беларускія рзлігійньїя дзеячы хx стагоддзя, (red. Ю. Гарбінскі), Мінск-Мюнхен 1999.

Смолич И. К., Русское Монашество: Возникновение. Развитие. Сущзность (988-1917), Москва 1999.

Сокол К., Русская Варшава, Москва 2002.

Теодорович Т., Почаевская лавра, Варшава 1930.

Цинкаловський О., Стара Волинь і Волинське Полісся, т. I, Вінніпег, 1984.

Цинкаловський О., Старовинні пам'ятки Волині, Торонто 1975.

Цыпин В., Истории Русской Церкви 1917-1997, Москва 1997.

Шкаровский М. В., Наџистская Германия и Православная Церковь (нацистская политика в отночении Православной Церкви и религиозное возрождение на территории СССР), Москва 2002.

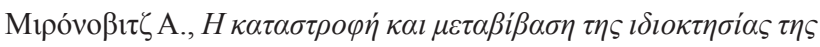

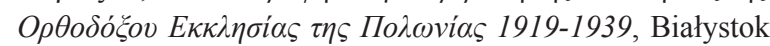
2013. 


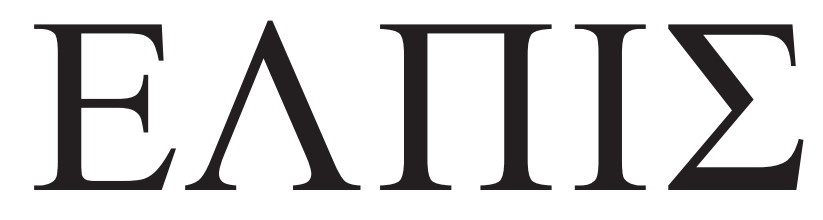

CZASOPISMO TEOLOGICZNE KATEDRY TEOLOGII PRAWOSŁAWNEJ UNIWERSYTETU W BIAŁYMSTOKU

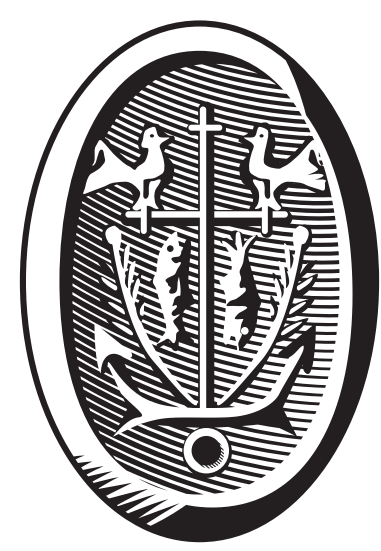

ADRES REDAKCJI

ul. Ludwika Zamenhofa 15, 15-435 Białystok, Polska tel. 85 745-77-80, e-mail: elpis@uwb.edu.pl www.elpis.uwb.edu.pl 